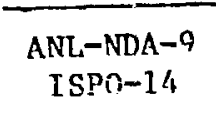

$$
\begin{aligned}
& \text { ANL-NDA- } 9 \\
& \text { DE82 } 011542
\end{aligned}
$$

THE BULK-ASSAY CALGRIMETER:

PART 1. SYSTEN DESIFN AND OPERATINN

PART Z. CALIBRATION AND TESTING

\begin{abstract}
by
R. B. Perry, C. T. Roche, A. L. Harkness, G. H. Winslow, G. A. Youngdahl, R. N. Lewis, * and F. A. Jung*
\end{abstract}

Nordestructive Assay Section
SPECIAL MATFRIALS DIVISLION

ARRONNF. NATIONAI, LABORATORY

9700 5. Cass Avenue

Argonne, I11inois 60439

January 1982

*Electronics Division

NOTICE

PORT'OUS OF TIIIS REPORT ARE ILLEAIDLE H

has heen reproduced from the bos avilath cony io pemit the broadeat nustble streff ahility.

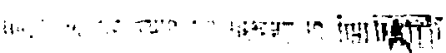


TABLF OF CONTENTS

Page

PART 1. SYSTEM DESIGN ANO OPERATION . . . . . . . . . . . 1

1. SYSTIM DRSCRTPTINN . . . . . . . . . . . . . . 1

II. SYSTEM START-IJP .................. 3

A. Component Interconnection and Power-up.... . . 3

B. Thernal Stahilization Period.......... 4

C. Internal Electrical Calibration ........ 5

il. SYSTEM CHECK-nUT ................ 6

A. DAS A/D Certification ........... 6

B. Power-Measurement Circuit Check . . . . . . 8

IV. SAMPLE ASSAY .................. 9

A. Paraineter Input ...... . . . . . . 9

B. Assay of Fissile Samples . . . . . . . . . . 10

C. Baseline Assay and Mass Computation . . . . . 12

V. PREHEATER OPERATION . . . . . . . . . . 17

vi. DATA ACQUISITION SYSTEM ............ 20

A. Physical Description............. 20

R. Keyhoard Action-Response........... . 20

VII. DATA ANALYSIS SOFTIARF . . . . . . . . . . 24

A. Fffective Specific Power . . . . . . . . . 24

1. Radinactive necay Correction . . . . . . 25

2. Effective Specific Power Calculation .... 26

B. Analysis of Sample Power... . . . . . . 28

1. Data Acquisition ............ 28

2. Data Analysis ............ 29

PART 2. CALIBRATION AND TESTING . . . . . . . . . . 33

I. CALIBRATION . . . . . . . . . . . . . . 34

A. Procedure . . . . . . . . . . . . . 34

B. Errors................ 38

C. Bias Correction .............. . 41

IT. HEAT DISTRIBITTIOR ERROR ............ . 41

IIT. PREHEATING TESTS ................ 44

IV. MEAStTREMFNT TIME ................ 47

V. ElEctrical Calibration ............... 49

RFFERENCES . . . . . . . . . . . . . . . 55

PARTS LIST AND SIIPPLIFRS . . . . . . . . . . . . . " 56

APPENDICES

A. CIRCUIT DIAGRAMS FOR RULK-ASSAY CALORIMFTER . . . 57-70

B. SCHEMATICS FOR TATA ACQUISITION SYSTEM . . . . . . 71-79 


\section{LIST OF ILLUSTRATIORS}

\section{Figure}

Page

1.

Bulk-Assay Calorimeter ............. 2

2. Effect of preheating on measurenent time ..... 19

3. Flowchart for operation of prediction routine . . . 32

4. Effect of preheat time on prediction....... 45 
This report describes the design and operating principles of the ANL Bulk-Assay Calorimeter. The calorimeter was originally constructed at ANL under ISPO Task A-9. Suhsequert modifications to the data analysis routines sere incorporated into the unit as part of a ioint task (ISPO A47) with Mound Facility-Monsanta. The software supplied by Mound enables the unit to predict and/or recognize the electrical end-point power applier when the system reequilibrates after sample insertion. The prediction algorithm is Hescrihed in "Real-Time Prediction of Calorimeter Fquilihrium," by C. L. Fellers and P. W. Seabaugh. ${ }^{1}$ Questions concerning the retails of the prediction code should he addressed to $C$. Fellers or $J$. Wetzel ai Mound-Monsanto, Miamishurs, Ohio 4534?. 


\section{PART 1}

THE BULK-ASSAY CALORIMETER:

SYSTEM DESIGN AND OPERATION

\section{SYSTEM DESCRIPTION}

The Bulk-Assay Calorlmeter (see Flg - 1) Is designed to measure the thermal power emitted by plutonium-contalning samples. The sample power range of this instrument is $1.4-22.4 \mathrm{~W}$. The maximum sample size is 10.8 $\mathrm{cm}$ in diameter and $25.0 \mathrm{~cm}$ In length. The Instrument package consists of the calorimeter measurement chamber (CMC), the control clrcult power bin (CCPB), and the data-acquisition system (DAS). Two sample preheating chambers and flve calorimeter canisters for contalning the samples are also included. This system is designed to operate on $230 / 240 \mathrm{~V}, 50 / 60$ cycle AC.

The calorimeter consists of five (5) concentric cylinders, four of whlch are temperz:ure-controlled. Their operating temperatures may be measured on the temperature-readout module. The outside cylinder has a measurement point on the inner and outer walls, labeled $T_{B}$ and $T_{S}$, respectively. The empty chamber equilibrium values are: $T_{3}-47.56^{\circ} \mathrm{C}$, $\mathrm{T}_{2}-45.58^{\circ} \mathrm{C}, \mathrm{T}_{1}-43.49^{\circ} \mathrm{C}, \mathrm{T}_{\mathrm{B}}-40.73^{\circ} \mathrm{C}, \mathrm{T}_{\mathrm{S}}-39.83^{\circ} \mathrm{C}$ (all temperatures approximately $\pm 0.1^{\circ} \mathrm{C}$ ). The modules in the control bin have front-panel meters which show the status of the various servo-circuits. When the system reaches operating status, all the circuits $\left(T_{3}, T_{2}, T_{1}, T_{S}\right)$ 


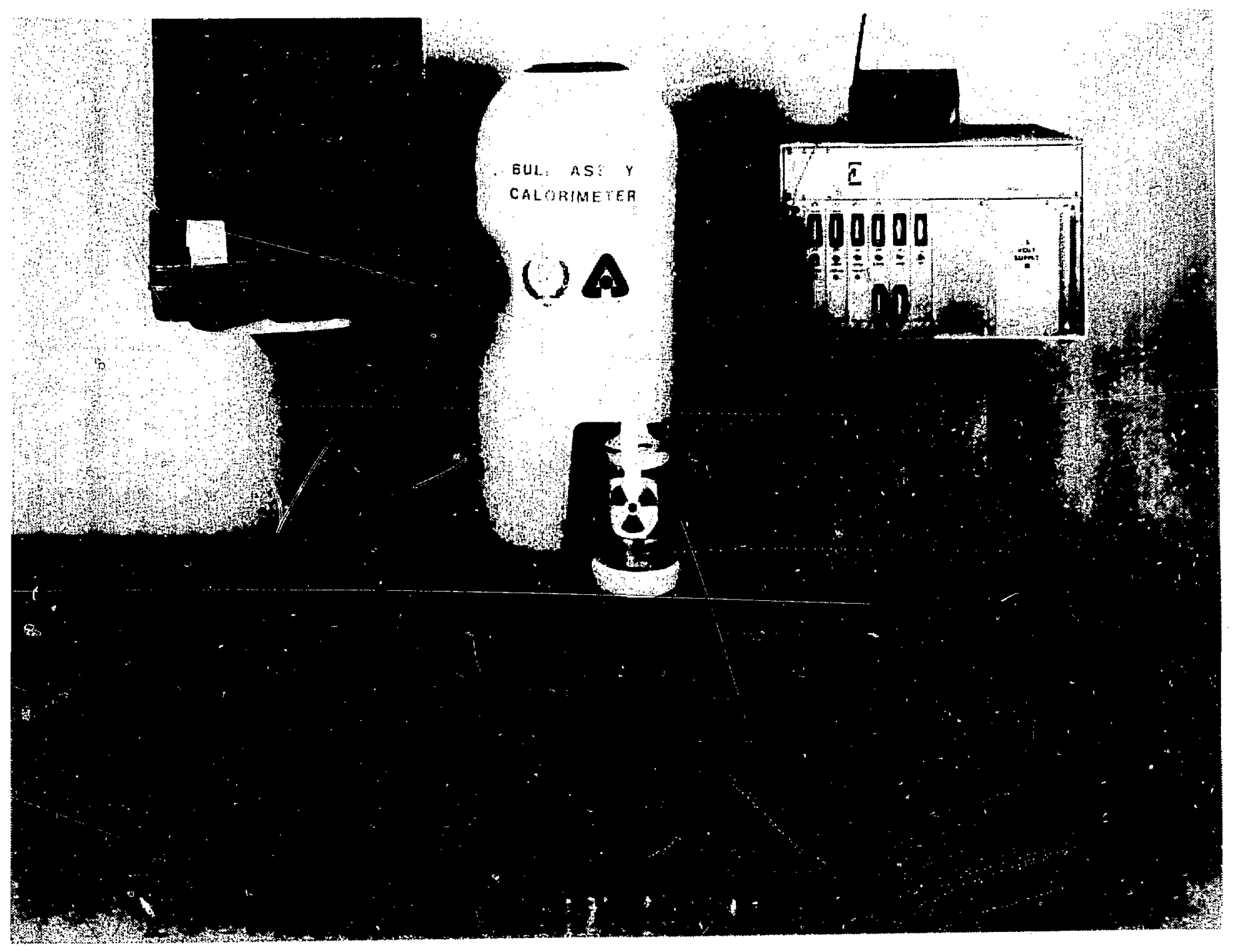

Fig. 1. Bulk-Assay Calorimeter. 
w111 zero on the coarse scale. A set of 32 test points which monitor voltages at points within the calorimeter and its control circuitry are accessed by the DAS. The points of interest to the operator are $\# 1$, \#2 (measurement-chamber voltage and current) and \#30-\$32 (A/D calibration points). The ise of the test points is described below.

\section{SYSTEM START-UP}

A. Component Interconnection and Power-up

Operator Action

1. Connect calorimeter neasurement

chamber (CMC) to the control

clrcult power bin (CCPB),

2 cables.

2. Connect the data-acquisition

system (DAS) to the CCPB,

2 cables.

Note: The cable connectors

have been chosen so that only

one connection sequence is

possible.

3. Connect the system power cord

to the bullding power. 
Operator Action

System Response

Note: The system is designed

for $230 / 240 \mathrm{~V}, 50 / 60$ cycle $\mathrm{AC}$.

4. Turn the system on with the

switch on the front panel of

the CCPB.

Bulk-Assay Calorimeter

Operation Sequence:

1. ELfCT CALIB

2. INPUT PARAMETERS

3. ASSAY SAMPLE

4. BASELINE ASSAY

B. Thermal Stabilization Period

Note: If the DAS did not respond after "power-up," tirn power off momentarily and turn on again.

The following automatic start-up sequence has been programmed into the DAS under the assumption that the system is at room temperature $\left(20^{\circ} \mathrm{C}\right)$ when powered up. The operator may abort this sequence at any time by pressing RST.

After printing the messages listed above, the DAS will watt for the operator to respond to 
"DLY (M)"

with a delay period (min) during which the instrument will reach operating equilibrlum. No data will be processed during this perfod. The default value is $0 \mathrm{~min}$. Since the DAS will determine when the system actually reaches equilibrium, an " 0 " response will result in a calibration being completed in minimum time. However, if the user allows the calorimeter to warm up overnight, a delay may be entered to ensure that the following calibration is performed just prior to sample assay in the morning. Allow $120 \mathrm{~min}$ for the electrical caltbration when determining the delay time.

\section{Internal Electrical Calibration}

After the delay perlod, the system will enter the automatic electrlcal calibration sequence. The DAS will determine the baseline power necessary to maintaln thermal equflibrium in the absence of a sample. This procedure takes approximately $30 \mathrm{~min}$. Next, the system will calculate the incremental power necessary to obtain a six (6) point electrical calibration. This power is applied to the electrical calibration coll, and both the applied power and the system response are measured. This procedure takes an additional $90 \mathrm{~min}$. A linear least squares fit is performed on the six-polnt data set, and the slope and intercept are stored. At this time, the system requires operator Interaction. The user may elect to perform a more detalled callbration checkout or to begin sample assay. 
III. SYSTEM CHECK-OUT

A. DAS A/D Certification

Note: Alteration of the $A / D$ calibration w111 affect the system Pu calibration. Do not adjust the slope control until you are sure of the test instrument calibration.

Connect the 4-1/2 digit multimeter supplied with the instrument to the test polnts at the hottom of the callbration module marked COM and VR. Check the A/D zero point by requesting test point 30 .

PRESS "TP"

TEST PTS

A/D CALIBRATE?

PRESS "ENTR" (NO)

ALL?

PRESS " 3,0 , ENTR"

The display should now read 00000. (Note: The display will blank if the voitage is between $\pm 0.1 \mathrm{~V}$ and is not 0 . If this occurs, a reading may be obtained by pressing "PRNT".) The zero adjustment is on the right side of the DAS panel above the keyboard and is screwdriver ad justable.

The slope of the A/D may be obtained by using the voltage-averaging 
A/D calibrate option of the TP routine.

SYSTEM RESPONSE

PRINT ALL

DELAY - MIN

\#DP/RUN

\# RUNS

TEST POINT 非

TEST PTS

A/D CALIBRATE
OPERATOR RESPONSE

PRESS "TP"

PRESS "YES"

PRESS "ENTR" (NO)

PRESS "0 ENTR"

PRESS "100 ENTR"

PRESS " 1 ENTR"

PRESS " 32 ENTR"

The program will average 100 voltage readings and will print the mean and the standard deviation of the mean. The average will also appear in the liquid crystal display (LCD). This number should agree with the DVM rearlings. To check the linearity of the $A / D$, measure 5 voltages covering the range $2-10 \mathrm{~V}$. The voltage is adjusted by turning the black knoh on the calibration module in the control bin. Press "YES" after each voltage adjustment to obtain the reading and record the DVM reading. After this procedure is completed, a zero reading may be obtained by pressing "ENTR" and changing the te,t point number to 30 . A least squares analysis of the data should be used to determine if the slope is significantly different from 1 before adjusting the slope. The slope control is at the top, right, of the DAS. Adjustment should be made with the voltage near $10 \mathrm{~V}$. Note: The DAS has a 12-bit A/D with 
a resolution of 0.0037 volts. This should be taken into consideration when attempting to adfust the siope.)

B. Power- Measurement Clrcult Check

Connect the DVM to the red and black test points on the front of the calibration module. With the switch in the E1 position, the voltage at the test points is the voltage across ?he calibration coil. With the switch in the E2 position, the voltage is proporticnal to the current through the calibration coll and staidard resistor. The power

$$
\mathrm{P}_{\text {DVM }}=(\mathrm{E} 1 \times \mathrm{E} 2) / \mathrm{R}_{\mathrm{STD}}
$$

where $\mathrm{R}_{\mathrm{STD}}=0.97514$ ohms

measured by the nVM should agree with the power printed by tine program. The measurement must be nade whlle the calibration progran is running, and the results should be fitted to a line using a linear least squares code. The calibration routine is started by pressing "CAL". The routine will first determine the baseline power and will calculate the incremental calibration power steps. After the "CALB" LED comes on, measure E1 and E2. Repeat for each of the data points. Do not read the DVM while the printer is operatirig as noise is introduced into the system. The fit of $P_{D V M}(x)$ vs $P_{C A L}(y)$ should give a slope of 1 and an intercept of 0 within the measirement precision. 


\section{A. Parameter Input}

Prior to sample assay, the operator may enter parameters which can be used in calculating sanple Pu mass from the power deterininaton.

SYSTEM RESPONSE

ASSAY PARAMETERS

(W)/(KG)

$3.674+1-0.0 i$

NORY

1.2

SIG(SYS)

$n .7$

The remaining parameters permit the operator to calculate the effective specific power from a set of sample isotoplc data. The user nay also update the isotoplc data to account for radioactive decay occurring since the Isotopic assay. Elther the elapsed time may be entered or the prorrad sill calculate the number of days between two dates. The isotopic percents are entered following the pronpt statements. The Am-241 must be entered as a percent of the total Pu. If the Am-241 is given as percent of total sample weight, then the rorrect value to enter is obtaineri by dividing the Am-24l by the weight 
fraction of $\mathrm{P}_{\mathrm{u}}$. The keys controlling the calculations are "FRAC." (decay) and "sp" (eifective specifte power). If the effective snecific power is known, this section can he skipped by pressing "RST".

B. Assay of Fissile Sampires

Refore a sample is measured in the Bulk Calorimeter, the sample container should be checked for surface cintamination and loaded into one of the calorimeter canisters provided with the instrument. The calorimeter canister containing the sample should then he placed into the preheater for a minimum of 30 ininutes. (For arditional information on preheatins, sre part 2, Sec. VI.) Cans of plutonium oxide, mixcd nxide or metal, with or without external nlastic hagging, san he placed directly into the calorimeter canister without heat sinking the container with shot. Small, concentrated heat sources, such as Pu-238 heat standards, can be nacked in copper or aluminum shot to reduce the measurement time and reduce the sample temperature. DO NOT PLACE $A$ SAMPLE DIRECTLY INTO THE CALORIMETER MEASUREMENT CHAMBER WITHOUT USING A CALORIMETER CANISTER. A significant loss of measurement precision and accuracy will result if a calorimeter canister is not used. In addition, the placing of concentrated, high-power heat sources directly into the calorimeter measurement chamber without using a calorimeter canister could damage the styrofoam insulating materials at the bottom of the measurement chamber, hecause these sources can have surface renperatares ahove the inelting noint of styrofoam.

After the calorimeter canister containing the sample is preheated, the canister should he quickly transferred to the calorimeter 
measurement chamber. Any delay during the transferring of the canister or In roplaring the lid of the meastrement chamber will increase

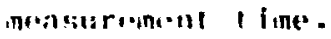

A sample assay ls a two-step process. The sinple powar is proportional to the difference between the calorimeter-applied electrical power necessary to maintati the systen at equilibrium in the presence or in the absence of a Pu sample. First, the Pu sampie is assayed (press "RUN"). The assay time varies from 2-5 hrs, depending on sample compostiton and the degree of preheating. After the DAS has determined the equilibrium electrical. power with the sample present, a baseline measurement (press " $\mathrm{P}_{0}$ ") must be taken. This takes approximately $45 \mathrm{~min}$. The sample power and mass are calculated at the end of this run.

The assay routines nay be operated by using a number of run-time options. The user may choose to: 1) print the Intermediate data points; 2) have the instrument predict the final thermal equilibrium value before It is reached; 3) halt data acquisition ifter a prediction or continie until the final equilibrium value is recognized.

Normal operation 1 s covered by the default options ( $1=$ No: $2=$ YES; 3 = YES). This may be selected by responding to the microprocessor prompt "DEFAULT OPTIONS?" with "YES". The system will monitor the calorimeter power until a thermal end point is predicted. It will print the final value with no Incermediate output.

A continuous $I / 0$ mode is avallable by responding as follows: 
DEFAUI.T OPTIONS?

DUMP MEAS PT?

USE. PRENLCT?
ENTR (NO)

YES

ENTR (NO)

A program check may be performed by requesting hoth prediction and equilibrium recopnition with intermediate $\mathrm{L} / \mathrm{O}$.

DEFAIILT OPT LONS?

DINP MFAS PT?

USE PREDTCT?

STOP AFTER PREDICT?
ENTR (NO)

YF.S

YES

ENT? (NO)

\section{Baseline Assay and Mass Computation}

$\Lambda$ system haseline measurement ends the assay sequence. It consists of determining the calorimeter applied power necessary to maintain thermal equilibrium in the absence of a sample. This $P_{n}$ check must be performed after the sample assay to use the mass calculation routines.

The sample nower is calculated as the difference hetween the "RUN" and " $\mathrm{P}_{0}$ " assays. This value is corrected for the slope determined in the electrical calibration and the operator input "NoRM" constant 
(tefault value $=1.0$ )

$$
P_{\text {sample }}=\left[\text { NORM } *\left(P_{0}-P_{C}\right)-A_{0}\right] / A_{1}
$$

The uncertainty in this value is given by:

$$
\begin{aligned}
& s\left(P_{S}\right)=\text { NOR!M } *\left[s\left(P_{0}\right)^{2}+s\left(P_{C}\right)^{2}\right]^{1 / 2} / A_{1} \quad\left(A_{n} \text { and } A_{1}\right. \text { have heen } \\
& \text { treated as constants) }
\end{aligned}
$$

The sample $P_{u}$ mass is determined using the operator-provided effective specific nower (ESP $W / K G$ )

$$
M=P_{\text {samnle }} / \text { ESP }
$$

The uncertainty in this value is given by

$$
s(M)=M *\left[\left(s_{S}\left(P_{S}\right) / P_{S}\right)^{2}+(s(\text { ESP }) / \text { ESP })^{2}+s S n\right]^{1 / 2}
$$

where $S S Q$ is the operator-supplied systematic uncertainty (default value $=n . n)$. 
SAMPLE DATA TAPE

DAS RESPONSF

BULK ASSAY CALORIMETFR

OPERATION SEQUENCE

1 - ELECT. CALIB.

2 - INPIJT PARAMETERS

3 - ASSAY SAMPLE

4 - RASELINE ASSAY

DLY (M) 3חO

CALIBRATE

EOIJR POWER (H)

$24.749+/=0.00199$

06 CAL PNTS

EQUK DLY (M) 05

0250 DP/RUN

CALIBRATE POHER (W)

0

MEAS POWER (V)

$24.749+1-0.00199$

CALIBRATE (W)

$4.2884+/-1.3091 \mathrm{E}-4$

MEAS POWER (W)

$20.457+1-3.4047$ E-4

CALIBRATE (H)

$8.3593+/-2.1760$ E -4

MEAS POWER (W)

:6.396 + $/-4.1555 \mathrm{~F}-4$

CALIRRATE (W)

$12.523+/=2.4123 \mathrm{E}-4$

MEAS POWER ( $\mathrm{H}$ )

$12.221+/-3.105 \cap E-4$

CAT,IBRATI: (U)

$16.785+/-3.0178$ F -4 MEAS POWER (W)

$7.9650+/-2.8623$ E-4
OPERATOR RFSPONSE

Assemble instrument and power up

Press 300 ENTR

( 5 hr telay) 
CALIBRATE (W)

$20.854+/-2.0715 \mathrm{E}-4$

MEAS POWFR (W)

$3.8916+/-2.6435 \mathrm{E}-4$

SIOPF.

$-1.0000$

INTCPT

24.748

ASSAY PARAMETERS

(W) $/(\mathrm{KC})$

$3.674+/-0.91$

NORM

1.0

SIG(SYS)

$n . n$

TLME

DAS RF.ANY

SYSTEM POWER (W)

$63 n$ D/RIIN

DFFAULT OPTIONS?

YES

PREDICT POWER ('V)

$20.947+/-0.00911$
Fnter effective specific power

Press 3.674 ENTR

Press 0.01 ENTR

Enter power normalization constant

Press 1.0 ENTR

Enter systematic error

Press 0.0 ENTR

The systematic error is approximately $0.0013 \mathrm{p}+0.0015$ watts. A value of 0.004 could be entered as a conservative estimate.

Skip ESP calculation

Press RST

Insert sample

Press RUN

Press YFS

(1.1-2.5 hr wait)

Remove sample

Press $P_{n}$

BASELLISF, POWER (W) 
$63 \mathrm{DP} / \mathrm{RUN}$

DEFAILT OPTIONS?

\section{YES}

EQUR POHER (W)

$24.749+/-0.00285$

BASELINF POWER (W)

$24.749+/-0.00285$

ASSAY PONER (W)

$20.947+/-0.0 n 911$

SAMPLF: PONER (W)

$3.8101+1-0.009 .55$

(IV) $/(\mathrm{KG})$

$3.674+/-0.00999$

PII (KG)

$1.0371+1-0.00384$
Press YES

(0.4-1.0 hr walt)
Sample power $=p_{0}-p+a_{0}$
$a_{n}=0.008$ is adfed as an
intercept correction. 


\section{PREHEATER OPERATION}

1. Plug the line cord into a $230 / 240 \mathrm{~V}, 50 / 60$ cycle AC outlet.

2. Turn the power switch to on, and press the reset button.

(The preheater is protected from overheating by a high-temperature limit switch that will de-energize the control relay and turn of the power. Press the reset button to resume operation. If the preheater does not cool with the power off, the sample may he overheating the preheater. If the relay continues to trip when the preheater is empty, there is a malfunction in the control circuit. An open control therinistor may be the cause.)

3. Connect the temperature output to the calorimeter temperaturereadout module.

4. After the calorimeter and the preheater have reached a stable operating temperature, the temperature of $T_{3}$ and the preheater can be compared by rotating the switch between $\mathrm{T}_{3}$ and $\mathrm{PH} 1$ or $\mathrm{PH} 2$. To raise the temperature of the preheater, rotate the temperature adjustinent control clockwise. The control calibration is approximately $1.5^{\circ} \mathrm{C} / \mathrm{turn}$.

The temperature of the preheater will read higher when there is a sample in the preheater. The temperature difference will depend on the sample power and the location of the sample in the calorimeter caniste:. Readjustment of the preheater temperature with a calorimeter canister in place is not required. 
A sample in its calorimeter canister should usually be preheated a minimum of 30 minutes, (See Part 2, Section III.) Normally, while one sample is being measured; another sample would be preheated, and several hours would therefore he avallable for preheating, except for the first sample. If the first sample is preheated for more than 30 minutes, the time spent in the preheater would probably not be mate up by time saved in the calorimeter.

The calorimeter power is plotted in Fig. 2 as a function of time, for preheating times from $30 \mathrm{~min}$ to $320 \mathrm{~min}$, to show the effect of preheating, on the measurement time. (This Hata is summarized in Table v, Part 2.) Samples with power outputs greater than 12 watts require less preheating. If the sample power is greater than 20 watts, the calorimeter canister may become hotter than the calorimeter operating temperature when the canister is allowed to warm up to a steady-state temperature in room-temperature air. Then the calorinieter sanister is placed into the calorimeter, both will cool slowly, and the measurement time will be longer than normal. Therefore, a high-power sample should be placed in a cold calorimeter canister and preheated until the preheater temperature reaches the calorimeter operating temperature. This wil only take 1n-15 min. The calorineter canister should then be placed immediately into the calorimeter measurement chamber to prevent overheat ing - 


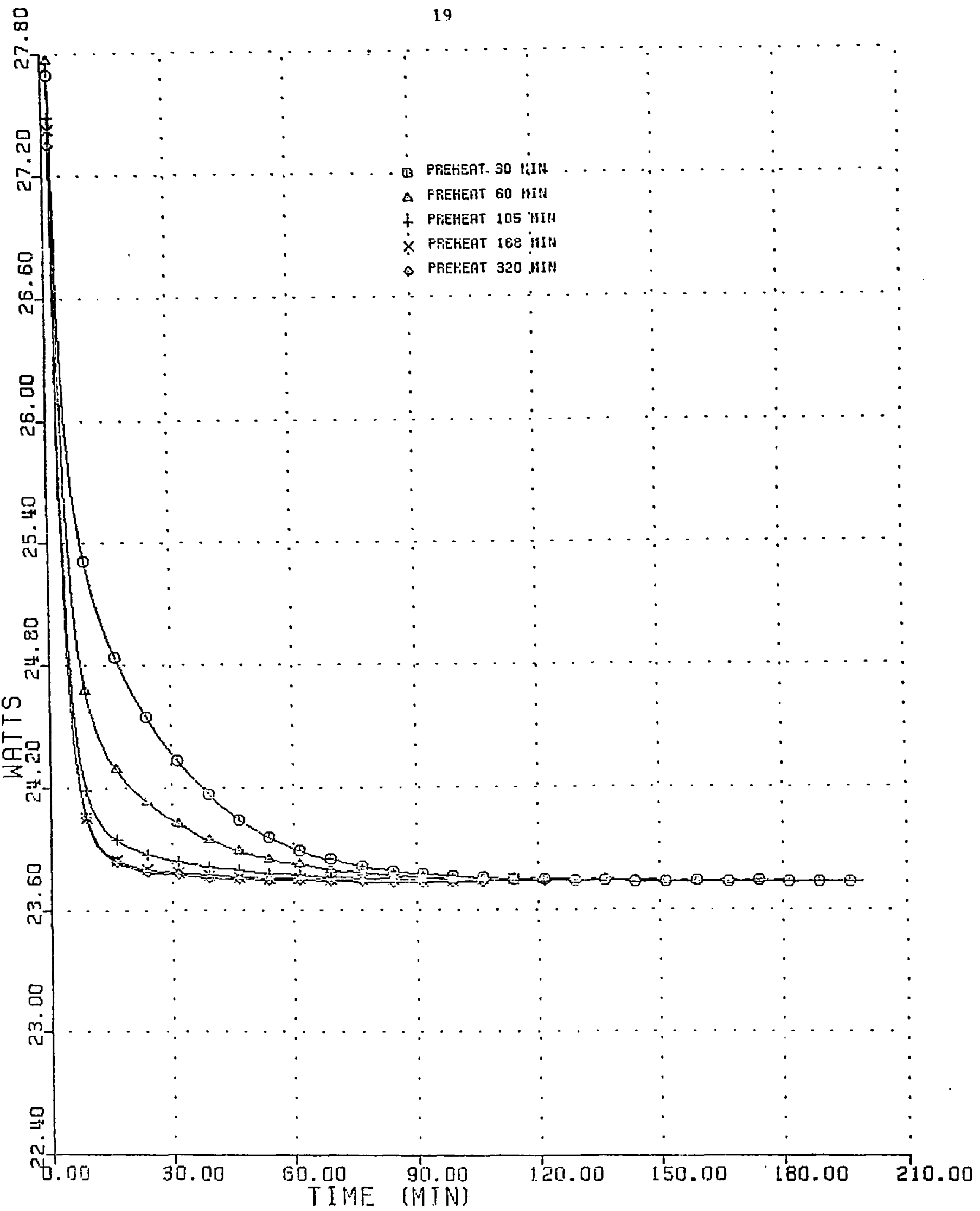

Fig. 2. Effect of preheating on measurement time. 


\section{DATA ACQUISITION SYSTEM}

\section{A. Physical Description}

The data-acquisition system (DAS) is housed in a $47-\mathrm{cm} \times 35-\mathrm{cm} x$ $16-\mathrm{cm}$ attache case and has a total weight of $5 \mathrm{~kg}$. It is a totally dedicated microprocessor-controlled device, designed around the INTEL 8085A. The system memory consists of $16 \mathrm{~K}$ bytes of erasable, programmahle, read-only memory (EPROM) and $1 \mathrm{~K}$ bytes of random-access memory (RAM). The prograin resides in the permanent memory, EPROM, and does not need to he reentered after the device is powered down. The EPROM is organized on four $4 \mathrm{~K}$-byte INTEL-2732 chips, the last $4 \mathrm{~K}$ bytes being exchangeable. The RAM is organized on four 256-byte INTEL-8156 chips and serves as scratch-pad storage for the program. The microprocessor receives input either from the calorimeter through the 12-bit ADC. or from the 25-key multifunctional keyhoard. System output is through either the BOMAR TP3120-2 printer or the liquid crystal display (LCD). A set of 6 LEDs are available to reflect system status. Detailed schematics are included in Appendix $B$.

\section{B. Keyboard Action-Response}

1. $\quad$ RST $=$ Restart

Function: To place the system in an inactive mode, where it will monitor the keyboard for a user command. All data processing is stopped. The results of any uncompleted calculation will not he avallable to the user. The system w11 also return to the inactlve node after complettng any noncyclical routtne. 
Use: This key should be used when aborting a particular routine.

Status Light: READY

Printer: DAS RFADY

2. $\quad$ ENTR $=$ Enter

Function: To signal the end of a numeric input. Use: This key should be used when responding to a microprocessor prompt statement with a numerical value. I: also acts as a "NO" in a situation requiring a YES/NO response.

Printer: Carriage return - Line feed

3. RS $=$ Backspace

Function: To pernit the user to erase an undesired response to a icroprocessor prompt statement prior to pressing ENTR. Use: This key repositions the input ASCII array by one character each time 1 t is pressed.

Printer: Rackspace

4. $\quad$ XXT = Execute external program

Function: To enable the user to expand the computational abilities of the DAS. The DAS is designed so that the last $4 \mathrm{~K}$ of the 16K PROM memory is interchangeahle by replacing the chip in the zero force socket with a different INTEL 2732 containing a new program. (CAUTION: Insertion of the chip upside down may cause damage to the system.)

Use: Reserved for future expansion.

5. $T P=$ Diagnostic test points

Function: To enable the user to examine the voltages of any 
of 32 selected locations within the calorimeter (see Annendix

A for TP locations within the calori neterl.

IIse: This routine may he used to

a) Continuously monitor a narticular point on the linuid crystal iisplay;

b) Ohtain a printout of all 3? noints;

c) Ohtain an average and standard deviation of the voltage of a narticular test point.

The use of this routine is descrihed in Part $T$, Sectinn $3 . A$, entitler "DAS $M /$ ! Certification."

Status light: $\quad N /$ ?

Liquid Crystal Display: TP voltare

6. PRINT $=$ Print

Function: To allow the user to nhtain a nrinted record of the value on the linuiri crystal display.

7. INIT = Initial parameter input

Function: To permit the user to innut parameters which will be used in data analysis hy the microprocessor.

Use: The use of this routine is descrihed in Part I, Section $\dot{4}$ A, entitled "Parameter Input."

8. FRAC = Mass fraction decay correction and effective specific power calculation

Function: To calculate the change in the mass nercentages in a previously isotopically analyzed sample resulting from radioactive decay. A current set of mass percent will he penerated which will then he used to calculate effectlve speciftc power. 
Ise: The proficam requires that the initial mass percent and the elapsed time he encered through INIT prior to execution. Printer: The deray-corrected Lsotopte mass pereent and the offective sperifir nower are printed.

9. $S P=$ Effective snecific power readout

Function: To check the value used for thermal porsr emitted Der gram of the material to he assayed as well as the associated uncertainty.

Printer: The effective specific power and its uncertainty.

1n. $P_{n}=$ F.npt" chamher haseline analysis

Function: To determine the power supplied by the calorimeter to maintain a constant temperature when no heat-producing source is present; to compare this with the nower when the sample is in place and derive the sample power and mass.

11. RUN = Sainple assay

Function: To determine the calorineter-supplied nover in the presence of a Pu-containing material.

12. CAL = Electrical calibration

Function: To supply a series of known electrical powers to the sample chamber, and to determine the resulting measured powers, thus allowing the user to derive a relation between the measured and actual sample power.

NOTE: A simulated output tape showing the results of typical operations is given in Section IV. 
VII. DATA ANALYSIS SOFTWARE

\section{A. Effective $S_{i}$ acific Power}

In order to obtain maximum utility from the calorimeter, the measured sample nower must be combined with additional isotopic information to determine the plutonium content of the sample. If the unknown contains only one isotope of plutonium, the generated heat is related to the sample mass by the equation

$$
W_{I T}=2.1193 \times M \times Q / T_{1 / 2} \times \Lambda
$$

where

$$
\begin{aligned}
& \mathrm{N}=\text { power }(\mathrm{nW}) \\
& \mathrm{M}=\text { mass of } \mathrm{Pu}(\mathrm{g}) \\
& \mathrm{Q}=\text { total disintegration energy (MeV) } \\
& \mathrm{T}_{1 / 2}=\text { half-life of the isotope of } \mathrm{Pu}(\mathrm{yrs}) \\
& \mathrm{A}=\text { gram atomic weight }(\mathrm{g})
\end{aligned}
$$

Under normal assay conditions, nuclear fuel will contain a mixture of radionuclides, the principal power producers being ${ }^{238-242} \mathrm{pu}$ and ${ }^{241} \mathrm{Am}$. Consequently, the sample power may be obtained from

$$
W_{U}=M \cdot \Sigma R_{1} \cdot P_{i}=M \cdot P_{\text {eff }}
$$

where 


$$
\begin{aligned}
& R_{i}=\text { mass fraction of the radionuclide } \\
& P_{i}=\text { specific power of a } P u \text { isotope } \mathrm{mW} / \mathrm{g} \\
& P_{E f f}=\text { effective specific power of the sample }
\end{aligned}
$$

Two techniques are suggested for determining the effective specific power. ${ }^{2}$ Representative samples may be suhsequently analyzed chemically to determine the $\mathrm{Pu}$ content (mW/g). This method usually requires multiple measurements distributed in time to account for isotopic decay. The second technique requires that the isotopic composition be determined by gamma-ray or mass spectrometry. ${ }^{3}$ Determination of radionuclide abundances by gamma-ray spectrometry has the advantage of being nondestructive and may be conducted concurrently with a calorimetric analysis. Thile the method chosen may differ from assay to assay, the programs supplied w: 11 work with either technique.

\section{Radioactive Decay Correction}

The isotopic mass ratios are continually charging owing to radioactive decay within the sample. In particular, the beta decay of ${ }^{241} \mathrm{Pu}$ to ${ }^{241} \mathrm{Am}$, which is a short-lived alpha emitter, results in an increase in the effective specific power with time. If a detailed isotopic analysis of the sample material has been made at an earlier date, an on-site determination of the mass fractions may be unnecessary. The present composition may be calculated by means of the following decay equations : 


$$
\begin{aligned}
F_{i}= & F_{i}{ }^{0} \exp \left(-\lambda_{i} t\right) / \Sigma F_{i}{ }^{0} \exp \left(-\lambda_{i} t\right) \\
F_{A M}= & {\left[1 \cdot \Sigma_{i}{ }^{0} \cdot \exp \left(-\lambda_{i} t\right)\right] \cdot\left[F_{A M}{ }^{0} \cdot \exp \left(-\lambda_{A N} t\right)\right.} \\
& \left.+\left[\lambda_{241} \cdot F_{241}{ }^{0} /\left(\lambda_{241}-\lambda_{A M}\right)\right] \cdot\left[\exp \left(-\lambda_{A M} t\right)-\exp \left(-\lambda_{241} t\right)\right]\right\}
\end{aligned}
$$

where

$\mathrm{F}_{1}^{0}=$ mass \% of $\mathrm{Pu}$ isotope at last analysis

$\mathrm{F}_{\mathrm{Am}}{ }^{n}=$ mass \% of ${ }^{241} \mathrm{Am}$ (relative to $\mathrm{Pu}$ ) at last analysis

$\lambda_{i}=$ decay constant of Pu isotope $\left(\mathrm{day}^{-1}\right.$ )

$\lambda_{\mathrm{AM}}=$ decay constant of ${ }^{241} \mathrm{Am}\left(\right.$ day $^{-1}$ )

$t \quad=\quad$ time elapsed since last analysis (days)

$\begin{array}{lr}\text { Isotope } & \text { Decay Constant } \\ { }^{238} \mathrm{Pu} & 2.1617 \cdot 10^{-5} \\ { }^{239} \mathrm{Pu} & 7.880 \cdot 10^{-8} \\ { }^{240} \mathrm{Pu} & 2.903 \cdot 10^{-7} \\ { }^{241} \mathrm{Pu} & 1.322 \cdot 10^{-4} \\ { }^{242} \mathrm{Pu} & 5.08 \cdot 10^{-9} \\ { }^{241} \mathrm{Am} & 4.372 \cdot 10^{-6}\end{array}$

See reference 2 .

2. Effective Specific Power Calculation

The effective specific power is defined as the weighted sum of the isotopic specific powers. The uncertainty in this value is dependent upon the measurement errors in both the isotopic mass fractions and the spectfic power. 


$$
\begin{aligned}
P_{\text {eff }} & =\sum_{i} F_{i} \cdot P_{i} / \Sigma_{i} F_{i} \\
\sigma^{2}\left(P_{\text {eff }}\right) & =\sum_{i}\left(\frac{F_{i} P_{i}}{\sum F_{i}}\right)\left(\frac{\sigma^{2}\left(F_{i}\right)}{F_{i}^{2}}+\frac{\sigma^{2}\left(P_{i}\right)}{P_{i}^{2}}\right)
\end{aligned}
$$

where

$$
\begin{aligned}
& \mathrm{F}_{\mathbf{i}} \quad=\text { mass } \% \text { of the radioisotope } \\
& \sigma\left(F_{i}\right) \quad=\quad \text { uncertainty in } F_{i} \\
& \mathrm{P}_{\mathbf{i}} \quad=\quad \text { isotopic specific power }(\mathrm{mW} / \mathrm{R}) \\
& \sigma\left(\dot{P}_{i}\right)=\text { uncertainty in } P_{i}(\mathrm{~mW} / \mathrm{g}) \\
& P_{\text {eff }}=\text { effective specific power }(\mathrm{mW} / \mathrm{g}) \\
& \sigma\left(\vec{F}_{\text {eff }}\right)=\text { uncertainty in } P_{\text {eff }}(\mathrm{mW} / g) \\
& \text { Isotope Specific Power (mW/g) } \\
& { }^{238} \mathrm{Pu} \quad 567.16 \pm 0.57 \\
& { }^{239} \mathrm{Pu} \quad 1.9293 \pm 0.0053 \\
& { }^{240} \mathrm{Pu} \quad 7.098 \pm 0.015 \\
& 241_{\mathrm{Pu}} \quad 3.390 \pm 0.002 \\
& { }^{242} \mathrm{Pu} \quad 0.1146 \pm 0.0003 \\
& { }^{241} 1_{\mathrm{Am}} \quad 114.23 \pm 0.16
\end{aligned}
$$

See reference 2 .

In general, there is a negligible increase in the uncertainty reported in the 1sotopic mass \% as a result of radioactive decay. This is not always the case for ${ }^{241} \mathrm{Am}$. If ${ }^{241} \mathrm{Am}$ was absent at the time of the original analysis, or only present in minute amounts, then changes in $\left({ }^{241} \mathrm{Am}\right)$ must be considered. 


$$
\sigma^{2}\left({ }^{241} \mathrm{Am}\right) \simeq\left[1.034 t\left(\lambda_{241}-\lambda_{\mathrm{AM}}\right) \cdot \sigma\left({ }^{241} \mathrm{Pu}\right)\right]^{2}+\sigma^{2}\left({ }^{241} \mathrm{Am}\right)
$$

\section{B. Analysis of Sample Power}

\section{Data Acquisition}

The calorimeter feedback circuitry adjusts the power supplied to the inner sylinder colls so that a constant temperature environment for the sample chamber is maintained. The inner coil $\left(\mathrm{T}_{3}\right)$ voltage and current are aiternately monitored by a 12-bit analog-to-digital converter (ADC), which transmits data to the microprocessor at a rate of ten readings/sec. Software multiplication of each voltage-current pair produces an "instantaneous" $\mathrm{T}_{3}$ power. Ten such ineasurements are averaged to produce a two-second reading which is displayed on the liquid crystal display. The system will then calculate the average power $\left[E\left(P_{1}\right)\right]$ supplied by the calorimeter and its standard deviation. Since the microprocessor performs floating-point arithmetic with five-digit software (NOVONICS FP 70R), it is necessary to use the following biasedaverage approach to maintain sufficient accuracy.

Given a set of power measurements

$$
\mathrm{P}_{\mathrm{i}} \quad \mathrm{i}=1, \mathrm{~N}
$$

Define a new set

$$
\hat{\mathrm{p}}_{1} \quad=\left(\mathrm{P}_{\mathrm{i}}-\mathrm{P}_{1}\right) \quad i=1, \mathrm{~N}
$$

then

$$
\begin{aligned}
\mathrm{E}\left(\hat{\mathrm{P}}_{\mathbf{i}}\right) & =\sum \hat{\mathrm{P}}_{1} / \mathrm{N}=\mathrm{E}\left(\mathrm{P}_{1}\right)-\mathrm{P}_{1} \\
\therefore \mathrm{E}\left(\mathrm{P}_{\mathbf{i}}\right) & =\mathrm{E}\left(\hat{\mathrm{P}}_{\mathbf{i}}\right)+\mathrm{P}_{1}
\end{aligned}
$$


Also, since

$$
\begin{aligned}
& P_{i}-F\left(P_{i}\right)=\hat{P}_{i}-F\left(\hat{P}_{i}\right) \\
& s^{2}\left[E\left(P_{i}\right)\right]=\sum\left[\hat{P}_{i}-F\left(\hat{P}_{i}\right)\right]^{2} /(N-1)(N)
\end{aligned}
$$

\section{Data Analysis}

The = sample chamber $\left(\mathrm{T}_{3}\right)$ is held at a constant temperature of $47.5^{\circ} \mathrm{C}$. Then no heat-producins source is present, the calorimeter supplies a constant nower, $P_{n}$, of approximately $24 \mathrm{~W}$ to maintain this temperature. Tf a sample containing, heat-producing plutonium is placed in the calorimenter, the power which the circuitry must supply to maintain $47.5^{\circ} \mathrm{C}$ drops to a lower value $\mathrm{P}_{\mathrm{c}}$. The radioactive decay produced power is the difference hetween the electrically supplied nower in the presence $\left(\mathrm{P}_{c}\right)$ and absence $\left(\mathrm{P}_{0}\right)$ of a sample when the calorimeter is at thermal equilibrium. The time elapsed hetween irsertion of the sample and the reestablishment of thermal equilibrium is denendent on sample temperature, sample comnosition, and thermal coupling hetween the sample and measurenent chamber. This time may vary from ?-5 hours, depenting upon the extent of sample preheating (see Section $V)$.

In order to increase sample throughput, a subroutine which predicts final equilibrium power has heen incorporated into the data analysis code. The user may reduce sample measurement time $3 n-50 \%$ with this routine (see Part 2, Section III). This code was developed by J. Wetzel and C. Fellers of Monsanto Mound Lahoratory using a previously tested algorithm. ${ }^{1}$ The aloorithm is hased on the assumption that, although the 
approach to equilibrium is exponential with multiple time constants, the final portion of this approach may be approximated by a single time constant. In this region, if the electrically supplied power is monitored at constant time intervals, the equilibrium value may be predicted by solving a single exponential growth/decay equation

$$
P_{t}=P_{E}\left(1+B e^{-\lambda t}\right)
$$

where

$$
\begin{aligned}
P_{t} & =\text { power at time } t \\
P_{E} & =\text { equilibrium power } \\
\lambda & =\text { system time constant } \\
t & =\text { tilie } \\
B & =\text { scaling constant }
\end{aligned}
$$

For a set of three data points equally spaced in time, $P_{F}$ may he solved as follows:

$$
P_{F}=\frac{P_{2}-P_{1} e^{-\lambda \Delta t}}{1-e^{-\lambda \Delta t}}
$$

The time constant is related to the measured power by

$$
e^{-\lambda \Delta t}=\frac{P_{3}-P_{2}}{P_{2}-P_{1}}
$$


If the assumption of a single time constant is valid, successive predictions will apree within random noise. The operation of this routine is shown schematically in Fig. 3 . 


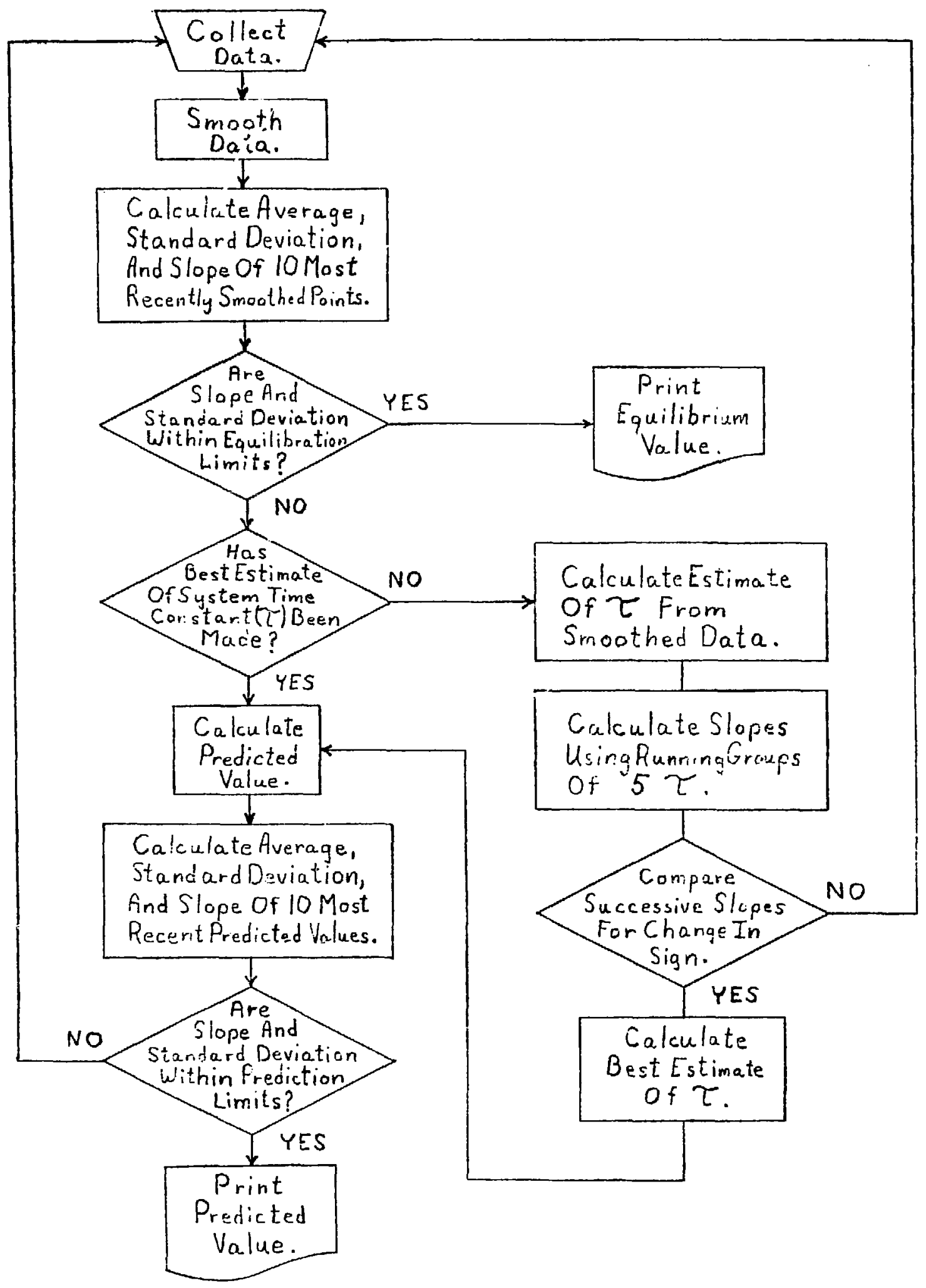

Fig. 3. Flowchart for operation of prediction routine. 
PART 2

\section{CALIBRATION AND TESTING OF THE \\ BULK-ASSAY CALORIMETER}

The Bulk-Assay Calorimeter was calibrated at 23 points with heat sources from 1.4 to 22.4 watts. The 23 measurement points defined a linear response function with sufficient precision to reduce the systematic error to less than the random error. The combined measurement error varied with sample power from $1.4 \%$ to $0.1 \%$ over the range of calibration measurements.

The instrument performance can be summarized as follows:

\begin{tabular}{lc} 
Wattage range & 1.4 to 22.4 watts \\
Systematic error & $0.06 \%$ to $0.02 \%$ \\
Random error & $0.7 \%$ to $0.05 \%$ \\
Uncertainty of a single & \\
measurement ( $95 \%$ & $1.4 \%$ to $0.1 \%$ \\
confidence level) & \\
Assay time, including baseline measurement: \\
\multicolumn{1}{c}{ Equilibrium } \\
$\quad$ Prediction
\end{tabular}

No bias between predicted and equilibrium values. The heat distribution error was not significant, compared to the random measurement error. 


\section{CALIBRATION}

\section{A. Procedure}

Two standards, corsistir.g of encapsulated Pu-238, were obtained from Mound Laboratory. The power of standard A was quoted as 1.9343 watts, and that of standard B as 3.8566 watts, as of June 28,1981 . The decay constant used by Mound for this material was $\lambda=0.0000213817$ days $^{-1}$. A third standard of 5.7909 watts was obtained by measuring $A$ and $B$ together. In order to calibrate over a range of 22 watts, a three-step procedure was used. In the following,

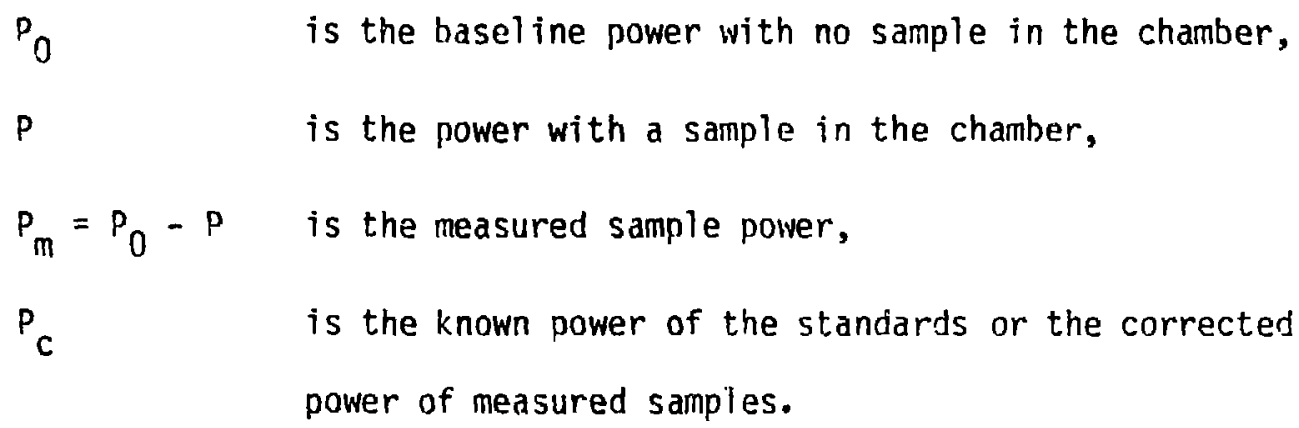

The power of standard A was measured twice, and that of standards $B$ and $A+B$ three times each. A least-squares fit of these eight points to the equation

$$
P_{m}=a+\beta P_{C}
$$

gives

$$
\alpha=-0.0108
$$




$$
\begin{aligned}
S(\alpha) & =0.0069 \\
B & =1.0091 \\
S(\beta) & =0.0016
\end{aligned}
$$

or

$$
P_{c}=0.9910 P_{m}+0.0107
$$

Power measurements were made for eight secondary standards which consisted of various numbers of plutonium-containing G-rods. The core weight of each of these rods is accurately known; they were all manufactured from the same lot of plutonium, and, therefore, all have the same specific power. Estimates of the true power, $P_{C}$, were obtained using the measured power and Eq. 2. A specific power was computed for each sample by dividing each $P_{C}$ by the corresponding core weight. The averaqe, $3.7777 \pm 0.00216 \mathrm{mw} / \mathrm{g}$, is the best estimate of the specific power of all samples. This average specific power, multiplied by the sample core weight, is the value used for the true total power, $P_{C}$, of the sample. A ninth secondary standard was made by measuring together the largest secondary standard (74G) and the two primary standards $(A$ and $B)$. The true value of this ninth standard was taken to be equal to the sum of the true values of its parts. A lirear ieast-squares treatment of the $P_{m}$ and $P_{C}$ data for the nine secondary standards, together with the data from the eight measurements of the primary standards, gives a calibration line to about 12.4 watts. The equation of this line is 


$$
P_{c}=0.99106 P_{m}+0.01064
$$

In orter to extend the calibrated range to about 22 watts, three tertiary standards were made by measuring three samples of Pu and obtaining estimates of their true powers with the calibration ?n. 3 . These samples are:

$$
\begin{aligned}
& \text { C - a quantity of high Pu-240 plutonium } \\
& \text { D - } 11 \text { Pu-238 pacemakers } \\
& \text { E - 22 Pu-238 pacemakers }
\end{aligned}
$$

Three additional points were obtained hy measuring together the standards $A+B+C, A+B+r+C$, and $A+B+C+E$. The true value of the power for the compound samples were taken as equal to the suris of the true nowers of their parts. A linear least-squares treatment of all 23 data points produced the calibration equation

$$
P_{m}=(1.00231 \pm 0.00019) P_{c}-(0.00812 \pm 0.00167)
$$

or

$$
p_{C}=n .9017 n p_{m}+.30305
$$

All calibration data are presented ir Table !. The true values for samples containing the primary standards $A$ and/or $B$ have heen corrected for decay to the date of measurement. 
\begin{tabular}{r|}
$\frac{0}{8}$ \\
0
\end{tabular}

जิ

농|

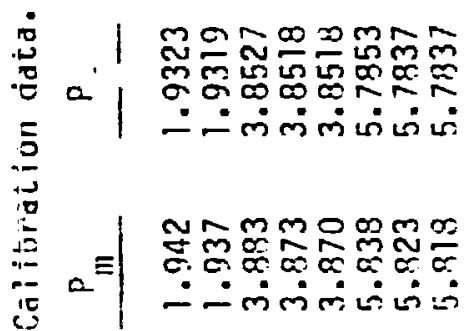

$\therefore$

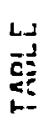

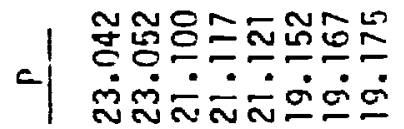

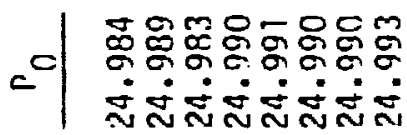

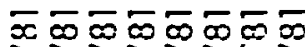

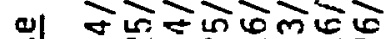

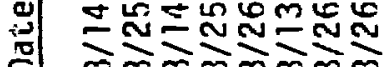

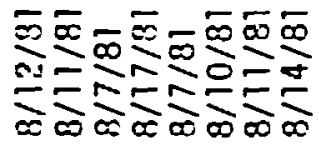

을

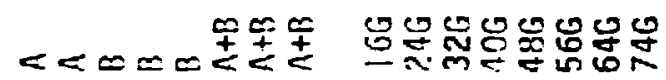

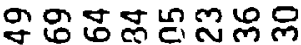

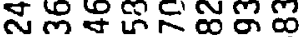

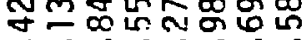
- $\dot{\sim} \dot{\sim} \dot{\sigma} \dot{\sigma} \dot{0}$

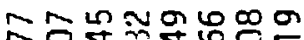
오ㅇㅝㅛ FNDENTE

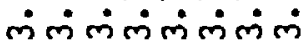

$8 \frac{6}{2}$

송

$\dot{m} \dot{+}$

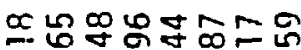

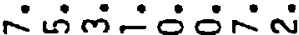

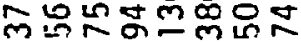

$\gtrless$

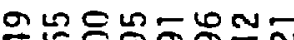

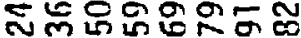

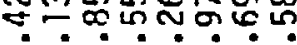

-

ก늠ำ

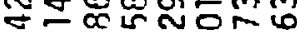

-

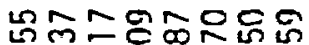

$\sim \infty-76$ on

ن்

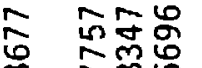

ल

$\therefore=\dot{0}$

$\overline{7}$

กำ

$\ln$

으노

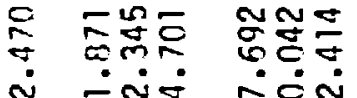

$\dot{\sim}=\dot{\sim} \dot{0} \dot{\check{N}}$

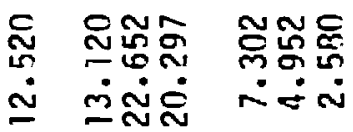

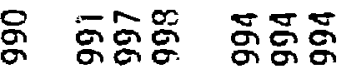

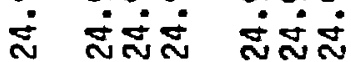

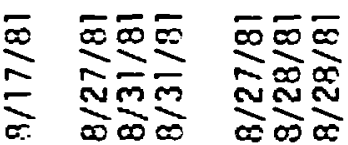

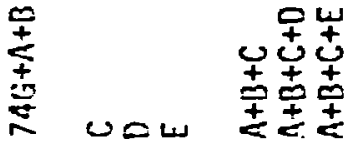




\section{B. Errors}

In the calibration process, the standard values, ${ }^{P} C$, were treated as the independent variable, and a regression of $P_{m}$ (the measured values) on $P_{C}$ was made to obtain an equation of the form of Eq. 1 .

Both $\alpha$ and $\beta$ have associated standard deviations, $S(\alpha)$ and $S(\beta)$. In practice, the measured power, $P_{m}=P_{0}-P$, is substituted into

$$
P_{C}=\left(P_{m}-\alpha\right) / B
$$

to obtain $P_{C}$, the sample power corrected ior bias. The measured power also has a standard deviation, $S\left(P_{m}\right)=\left[S^{2}\left(P_{0}\right)+S^{2}(P)\right]^{1 / 2}$.

Applying the usual rules for the prodagation of errors, the variance of the corrected sample power is

$$
S^{2}\left(P_{C}\right)=\frac{S^{2}\left(p_{m}\right)}{B^{2}}+\frac{S^{2}(a)}{B^{2}}+\frac{\left(p_{m}-\alpha\right)^{2} S^{2}(s)}{B^{4}}
$$

The first tem on the right side of this equation is the random error due to the uncertainties in the measurement being made. The last two terms are fue to the uncertainties in the calibration equation and are, therefore, a systematic component of the error in all measurements in wich this equation is used. Substituting the numerical values of Eq. : into Fq. 7, we obtain 


$$
\begin{aligned}
S^{2}\left(P_{s}\right)= & 0.9835 \mathrm{~S}^{2}\left(P_{m}\right)+3.49 \times 10^{-8} P_{m}^{2} \\
& +5.67 \times 10^{-10} P_{m}+2.74 \times 10^{-6}
\end{aligned}
$$

The last three temis make up the systenatic portion of the variance, $s^{2}\left(P_{c}\right)$. This varies from about $(? .0017)^{2}$ watts ${ }^{2}$ for a 2watt sample to $(0.0048)^{2}$ watts $^{2}$ for a 24 -watt somple. Table II lists the systematic standard deviations for sample powers of 1 to 24 watts.

The constants of the calibration line have been iacorporated into the program for the calorineter so that the sample nower that is printed is the corrected value, ${ }^{P} c$. The standard deviation that is printed is the random measurenent error and does not include the systematic error due to the calibration. This latter portion can be obtained, by interpolation, from Table II. If we let $S_{r}$ be the random measurement standard deviation and $S_{S}$ be the systematic calibration standard deviation, then the total standard deviation is

$$
S\left(P_{C}\right)=\left[0.9836 S_{r}^{2}+S_{S}^{2}\right]^{1 / 2}
$$

For example, if the sample power measured is $6.631 \pm 0.00176$, then

$$
S\left(P_{C}\right)=\left[0.9836(n .00176)^{2}+(0.00206)^{2}\right]^{1 / 2}=0.00270
$$


TARLF. II. Systematic standard deviations.

$\begin{array}{lr}\begin{array}{l}\text { Sample } \\ \text { Power }\end{array} & \text { S(Cal) } \\ & \\ 1.0 & 0.00166 \\ 2.0 & .00169 \\ 3.0 & .00174 \\ 4.0 & .00181 \\ 5.0 & .00189 \\ 6.0 & .00199 \\ 7.0 & .00210 \\ 8.0 & .00222 \\ 9.0 & .00234 \\ 10.0 & .00248 \\ 11.0 & .00262 \\ 12.0 & .00276 \\ 13.0 & .00292 \\ 14.0 & .00307 \\ 15.0 & .00373 \\ 16.0 & .00339 \\ 17.0 & .00355 \\ 18.0 & .00371 \\ 19.0 & .00387 \\ 20.0 & .00405 \\ 21.0 & .00422 \\ 2.2 .0 & .00439 \\ 23.0 & .00456 \\ 24.0 & .00473\end{array}$




\section{Bias Correction}

The final values for the slope and intercept given in Eq. 5 were incorporated in the microprocessor program to remove the measurement bias. The calibration was verified by repeating measurements on the standard heat sources. These measurements are summarized in Table III.

The average difference between the measured and the expected value was - 0.0014 watts, and the t-test showed that the difference is not statistically significant. The variance $S_{D}{ }^{2}=s_{r}{ }^{2}+s_{0}{ }^{2}$, where $s_{0}{ }^{2}$ is the variance in the standards and $S_{r}{ }^{2}$ is the random error variance. Since the variance in the standards is much smaller than the measurement variance, $S_{D}{ }^{2}$ is a good estimate of the random error variance. When the earlier estimates, hased on 9 measurements of the same source and nine heat distribution error measurements, are pooled with the above, an average value for $S_{r}$ of 0.0094 is obtained. This was rounded to 0.01 watts, which agrees very well with the average value printed out by the prediction program for the error in the measured power.

\section{HEAT DISTRIBUTION ERROR}

Heat-distribution error measurements were made with a 2-watt heat source at the top, center, and bottom of the sample canister on the centerline and on the canister wall. The analysis-of-variance F-test for means was used to evaluate the data shown in Table IV. 
TABLE III. Standard heat source measurements.

\begin{tabular}{|c|c|c|c|c|}
\hline Measured & d Power & Expected Pow & & \\
\hline & $\mathrm{P}_{\mathrm{S}}$ & $A$ & & $P_{S}-A$ \\
\hline $5.7726 \pm$ & \pm 0.0044 & 5.7804 & & -0.0078 \\
\hline $3.8354 \pm$ &. \pm .0060 & 3.8496 & & -0.0142 \\
\hline $1.9297 \pm$ & \pm .0038 & 1.9308 & & ווד \\
\hline $5.7795 \pm$ & $\pm \quad .0082$ & 5.7803 & & -0.0008 \\
\hline $1.9331+$ & \pm .0071 & 1.9308 & & 0.0023 \\
\hline $3.8573 \pm$ & \pm .0329 & 3.8495 & & 0.0078 \\
\hline $5.7770 \pm$ & $\pm \quad .0029$ & 5.7803 & & -0.0033 \\
\hline $3.8452 \pm$ & \pm .0033 & 3.8495 & & -0.0043 \\
\hline $1.9394 \pm$ & \pm .0075 & 1.9307 & & 0.0087 \\
\hline & & $\overline{0}$ & $=$ & -0.0014 \\
\hline & & $S_{D}$ & $=$ & 0.0072 \\
\hline & & $\mathrm{S}_{\bar{D}}$ & $=$ & 0.0024 \\
\hline
\end{tabular}


TABLF. IV. Heat distribution measurements.

Top

$\begin{array}{llll}\text { Centerline } & 2.3435 & 2.3460 & 2.3230 \\ \text { Centerline: } & 2.3484 & 2.3580 & 2.3415 \\ \text { Side } & 2.3381 & 2.3513 & 2.3386 \\ & & & \\ \bar{x} & 2.3433 \pm 0.0057 & 2.3518 \pm 0.0060 & 2.3344 \pm 0.0099\end{array}$

Center Bottom 
The calculated F-ratio was 4.?1 compared to the critical F-ratio of 9.55 at the $95 \%$ confidence level. The combined standard deviation of the nine measurements was 0.010 watts, compa:ed to 0.011 for nine measurements of a source located in the center of the canister. It is concluded that the heat distribution error is not significant compared to the random error.

\section{PREHEATING TESTS}

A series of tests were made on identical 1.2-watt samples to determine the effect of preheating on measurement time. The test results are summarized in Table $v$. These results show that the time saved by preheating is approximately $50 \%$ for both prediction of equilibrium and equilibrium power measurements. The time required for prediction approaches a minimum value faster than the time for equilibrium. Therefore, when prediction is used, the first sample of the day need only be preheated for 30 min before insertion into the calorimeter. Longer preheat time will not be compensated for by the time saved in the calorimeter. Higher powered samples could be preheated faster due to the self-heating of the plutonium.

The calorimeter power is shown as a function of time in the composite plot shown in Fig. 4 for the preheat times given in Table IV. The prediction does not occur until the power has fallen to within $99.8 \%$ of its final value. Therefore, the faster the power approaches equilibrium, the shorter the measurenent time when prediction is used. 


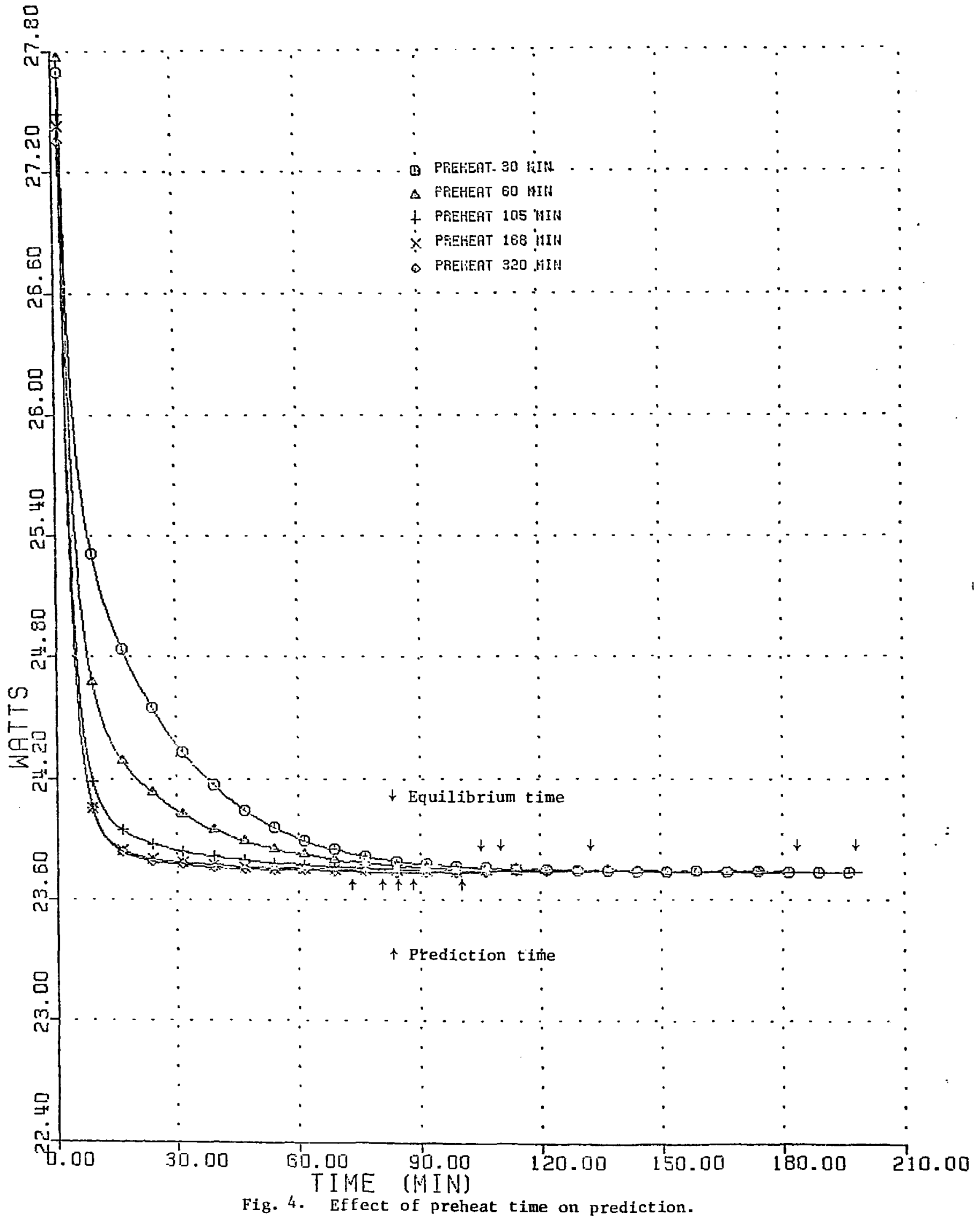


TABLE V. Effect of preheating on measurement time.

Preheat

Time Minutes

0

30

60

105

168

320
Prediction

Time $\underline{\text { Reduction }}$

143

101

86

83

80

74

42

44

48
Equlilibrium

Time \% Reduction

210

204

$3 \%$

182

13

128

40

114

46

106

49 


\section{MEASUREMENT TIME}

The measurement tin:e was recorded for 28 sample measurements with varying sample power and sample packaging. The time for prediction of equilibrium ranged from 1 to 2.5 hours. The time to reach equilibrium ranged from 1.4 to 5.4 hours. The time for the haseline measurement varied from 0.4 to 1.3 hours. The equilibrium value for the baseline power was obtained before a prediction coulc be made in 23 of the 28 cases. This data is summarized in Table VI.

If prediction of equilibrium is used, the average time for a sample measurement, including the baseline measurement, is $130 \mathrm{~min}$. or 2.17 hours. Measurement of three samples a day, including a 30-min preheat for the first sample, would take 7 hours. It has been demonstrated that four samples can be measured in one day, starting with room-temperature samples. The first sample was preheated for $30 \mathrm{~min}$, and the other three samples were prehecited in the two preheaters while the measurements were made. The measurement time, including baseline, was:

$\begin{array}{ll}\text { Sample } 1 & 150.0 \text { min (including } 30 \text {-min preheat) } \\ 2 & 121.5 \mathrm{~min} \\ 3 & 118.5 \quad \\ 4 & 108.0 " \\ \text { Total } & 498 \mathrm{~min}=8.3 \text { hours }\end{array}$

The average time saved by the prediction of equilibrium program is 48 $\min /$ sample, or $27 \%$. 
TABLF VI. Summary of measuremerit-time data.

Sample

Prediction Equilibrium

$\begin{array}{lcc}\text { N } & 28 & 28 \\ \text { Min. } & 1.1 \text { hours } & 1.4 \text { hours } \\ \text { Ave. } & 1.5 " & 2.3 " \\ \text { Max. } & 2.5 " & 5.4 " \\ \text { S } & 0.3 " & 0.8 "\end{array}$

$P_{0}$ no prediction Equilibrium

23

0.4 hours

$0.65 \quad$

$1.0 "$

$0.16 "$
$P_{0}$

Prediction Equilibrium

5

0.95 hours $\quad 1.4$ hours

$0.95 " 1.2 "$

$0.95 " 1.3 "$

$0 \quad$ ' $0.05 "$ 
A paired-difference test of the prediction and equilibrium values of measurements covering the range of the calorimeter showed no statistically significant difference. This data is summarized in Table VII.

\section{ELECTRICAL CAL IBRATION}

There is a three-step procedure for verifying the valibration of the electrical measurement functions of the calorimeter. The first step is calibration of the analor-to-digital converter (ADC) in the dataacquisition system (DAS). The slope and zero were checked frequently during the calibration and testing of the instrument. No drift in the slope or zero was observed, and no recalibration was required. An example of the ADC test data is shown in Table VIII.

The sample chamber is provided with a calibration winding so that the response of the power measurement circuits can be verified. The microprocessor program has a calibration subroutine that measures the response at six points, covering the range of the instrument. A linear least-squares program calculates the slope and intercept. An example of the calibration test program data is given in Table IX. This program checks the linearity of the sample chamber power measurement circuits.

While this program is running, the voltage and current to the calibration coil can be measured with an external digital multimeter (DMM) at test points on the front panel of the calibration module. Data taken with the $4-1 / 2$ digit DMM that is being supplied with the 
TABLF VII. Paired-difference test.

Equilibrium

$$
\begin{gathered}
0.3593 \\
1.4267 \\
2.1443 \\
2.8647 \\
3.5804 \\
4.2954 \\
5.0123 \\
5.7311 \\
6.6289 \\
12.465 \\
5.8364 \\
3.882 \\
1.9412 \\
17.686 \\
20.035 \\
22.407
\end{gathered}
$$

\section{Prediction}

0.3593

1.4297

2.1443

2.8687

3.5804

4.3044

5.0313

5.7311

6.6269

12.488

5.8364

3.878

1.9372

17.684

20.034

22.405

\section{Difference}

0

$+0.0030$

0

$+0.0040$

0

$+0.0090$

$+0.0190$

0

$-0.0020$

$+0.0230$

0

$-0.0040$

$-0.0040$

$-0.002$

$-0.001$

$-0.002$

\footnotetext{
Std dev. of mean diff $\left(S_{\bar{D}}\right) \quad 0.0020$

Std dev.of single $\begin{array}{ll}\text { diff. }\left(S_{D}\right) & 0.0079\end{array}$

Mean diff. (D) $\quad 0.0027$

Test statistics $t=1.3686$ (critical value $2.13195 \%$ C.L.)

Deg. freedom 15

N 16
} 
TABLE VIII. ADC test.

DVM

0.0000
1.9647
4.0002
6.0013
3.0011
9.9895
$\underline{A D C}$

0.0000

1.9643

4.0001

6.0016

8.0016

9.9895

\section{Least-Squares-Fit}

$a_{0}=-0.00036$

$a_{1}=1.000070$

$r^{2}=0.99999999$

$S_{y x}=0.000316$

$S_{0}=0.00033$

$S_{1}=0.000050$ 
TABLE IX. Calibration test program.

\begin{tabular}{|c|c|c|c|}
\hline Slope & Intercept & Baseline & Comment \\
\hline-1.0004 & 24.951 & 24.953 & $6 / 17 / 81$ \\
\hline-1.0003 & 24.975 & 24.975 & $7 / 8 / 81$ \\
\hline-1.0000 & 24.977 & 24.980 & $7 / 22 / 81$ \\
\hline-1.0002 & 24.982 & 24.982 & $8 / 7 / 81$ \\
\hline-1.0000 & 24.748 & 24.749 & $\begin{array}{l}9 / 30 / 81 \text { after bias } \\
\text { correction }\end{array}$ \\
\hline-1.0004 & 24.785 & 24.785 & $10 / 8 / 81$ \\
\hline
\end{tabular}


calorimeter is given in Table $X$. This data provides a slope that can be used as a basis for determining if the instrument calibration has changed.

The applied power is equal to

$$
P=E_{V} \times \frac{E_{I}}{R}
$$

The slope determined by the least-squares-fit to the data in Table $X$ gives the value of $R$. A t-test indicates that the intercept is rot statistically significant, so that it is effectively equal to zero.

The " $R$ " determined by this data includes the normalizing constant used to remove the bias determined by the heat standard calibration. Any change in the instrument calibration will be detected by repeating the electrical measurements, using "R" to calculate the power and testing to see if the data gives a slope of " 1 " and an intercept of zero within the measurement precision. 
TABLE X. IAEA Bulk Calorimeter calibration. $E_{V}$ and $E_{I}$ measurements made with Keithley-135 DMM.

$\begin{array}{cccc}E_{V} & \times E_{I} & \underline{E_{V}} \times E_{I} & \underline{P_{D A S}} \\ 9.214 & 0.4544 & 4.187 & 4.2884 \\ 12.852 & .6335 & 8.142 & 8.3483 \\ 15.739 & .7757 & 12.209 & 12.518 \\ 18.225 & .8987 & 16.368 & 16.782 \\ 20.43 & 1.0065 & 20.563 & 21.083\end{array}$

$$
\begin{aligned}
& a_{0}=0.0032 \\
& a_{1}=0.97514 \\
& r^{2}=0.99999994 \\
& s_{y x}=0.00180 \\
& s_{0}=0.00188 \\
& s_{1}=0.000135
\end{aligned}
$$




\section{REFERENCES}

1. C. L. Fellers and P. W. Seabaugh, "Rea1-Time Prediction of Calorimeter Equilibrium," Nuclear Instruments and Methods 163, 499505, North Holland Publishing Co., (1979).

2. "American Nationa1 Standard Calibration Technique for the Calorimetric Assay of Pu-Bearing Solids Applied to Nuclear Materials Control," American National Standard AINSI N15.22-1975, American National Standards Institute, New York (1975).

3. R. Gunnink, "Determination of Plutonium Isotopic Abundances by GamuaRay Spectroscopy," IICRI,-52879, March 1980. 
PARTS LIST AND SUPPLIERS

Only parts that may be dificult to obtain are listed.

PARTS

Printer, Bowmar Model TP3120

Printhead, Thermal 220722-1

Printer paper, 2-1/4 wide $\times 2$ " diameter, \#10-8:9-1
SUPPLIER

Bowmar Insitrument Co. 4640 - 126th Ave. North

Clearwater, FL 33520

Analog-to-Digital Converter AD7550BD

Digita1-to-Analog Converter AD7522KN

Multiplexer AD7506JD

Analog Devices

Route One Industrial Park P.0. Box 280

Norwood, MA 02062

Display, LCD Hamlin 3918-312

Hamlin, Inc.

Lake \& Grove Streets

Lake Mills, WI 53551 
APPENDIX A

Circuit Diagrans for Bulk-Assay Calorimeter

Sheets 1 through 12 
Notes:

(1) The tua innormocti cylindere have had throade cut in them (boe deto,l below). The copper heater coils and Dat nickel sensing coils were then wound in the

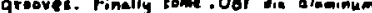
wire wat wound over the groouse, seeling the coils inside, to kesp epoxy from flowing onto them during assembly. The senter cylinder has twe co.te wound with 30 p. copper we...

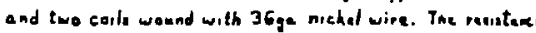
of the coppor coilo are 18.7 a and $18.7 \mathrm{\Omega}$. The nicket corls are $1.59 \mathrm{~K} \Omega$ and $1.58 \mathrm{~K} \Omega$. The second cylinder has one coil wound with 30, cosper wire and two couls wound with 36 yo nickel wire. The copper cail is $20.8 \Omega$ and the nickel coils are $1401 \Omega$ and $1404 \Omega$. Each cylinder had five Fenvall UUA $33 \mathrm{JI}$ thermottera imbeded in the cylinder wall and wired in serries. Each cylinder alsa has a YSI temperature probe imbedad in the wall for tempurature masusurement.

(2) The third and fourth eylinders from the canter are wound with teflouth eylunders from the canter are wound with teflion coated 32 ge hookup wire. The resiittance of the third corl is $41.4 \Omega$, and the fourth coil maasures $63.7 \Omega$. The third coil has nine Fenwall UUA33JI theremisters opoxyed to the inside wall. These are wired in serries with a top after every third one. The fourth coil ha twalve Fenualt uUAзэJI thermisters eporyed to the insede

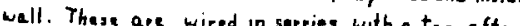
every fourth a ne. Both colls have a YSI temperature probe imbeded in the wall for temperater measure ment.

(3) The fifth (outermost) cylinder has no call wound on it. There are twalue Finnell theraistere sired in serries and eponyed to the inede wall. There a tap after enery fourth thermister giveng throe lege of four thorm, it ars cach. Each leg consist, of throe GB 32 P2 (2000n) thermuters and one GB31 P2 (1000 $\Omega$ ) the rmicter.

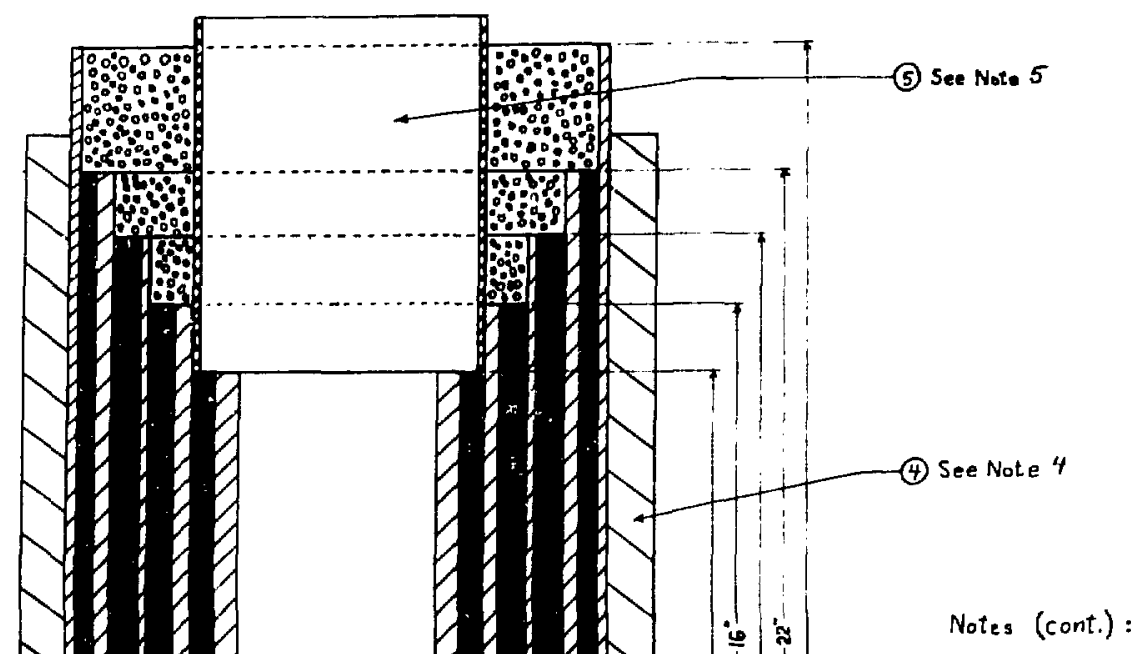

(4) The outer cylinder has 37 fins made from 1". 1 "right angle aluminum stock. These fins are to increase the heat disipation from this cylinder. (5) A st yrofoam plug is to ship fit into the plexiglass tube to insulate the sample chamber during operalion.

Key
Aluminum
Epoxy
Styrofoam
Plexiglass

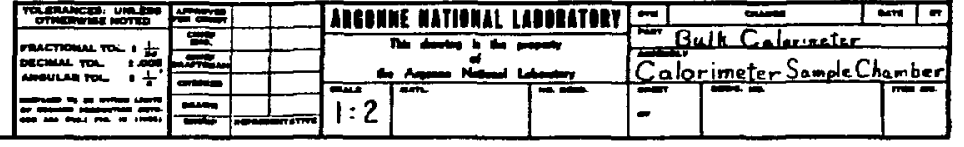




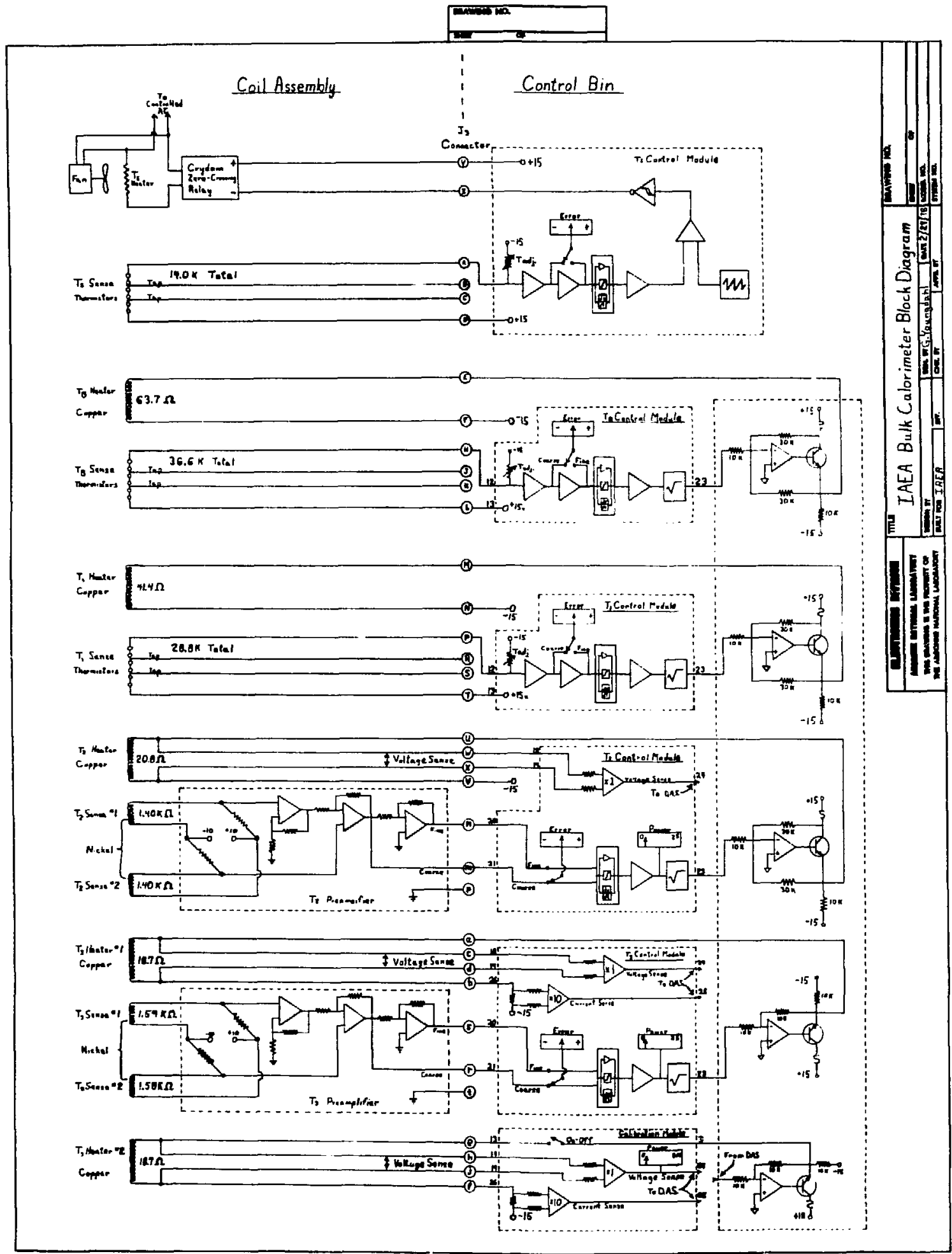


D

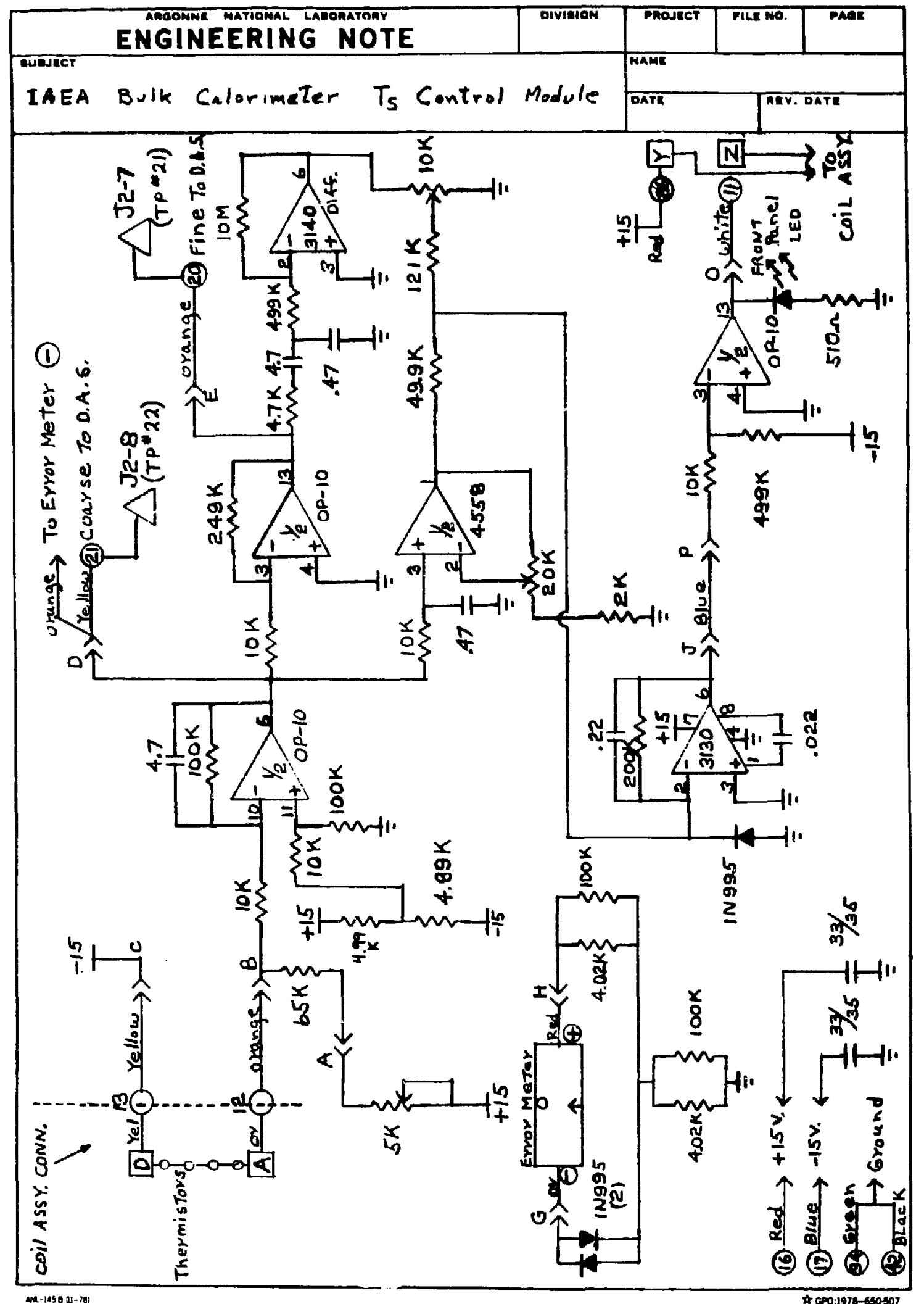




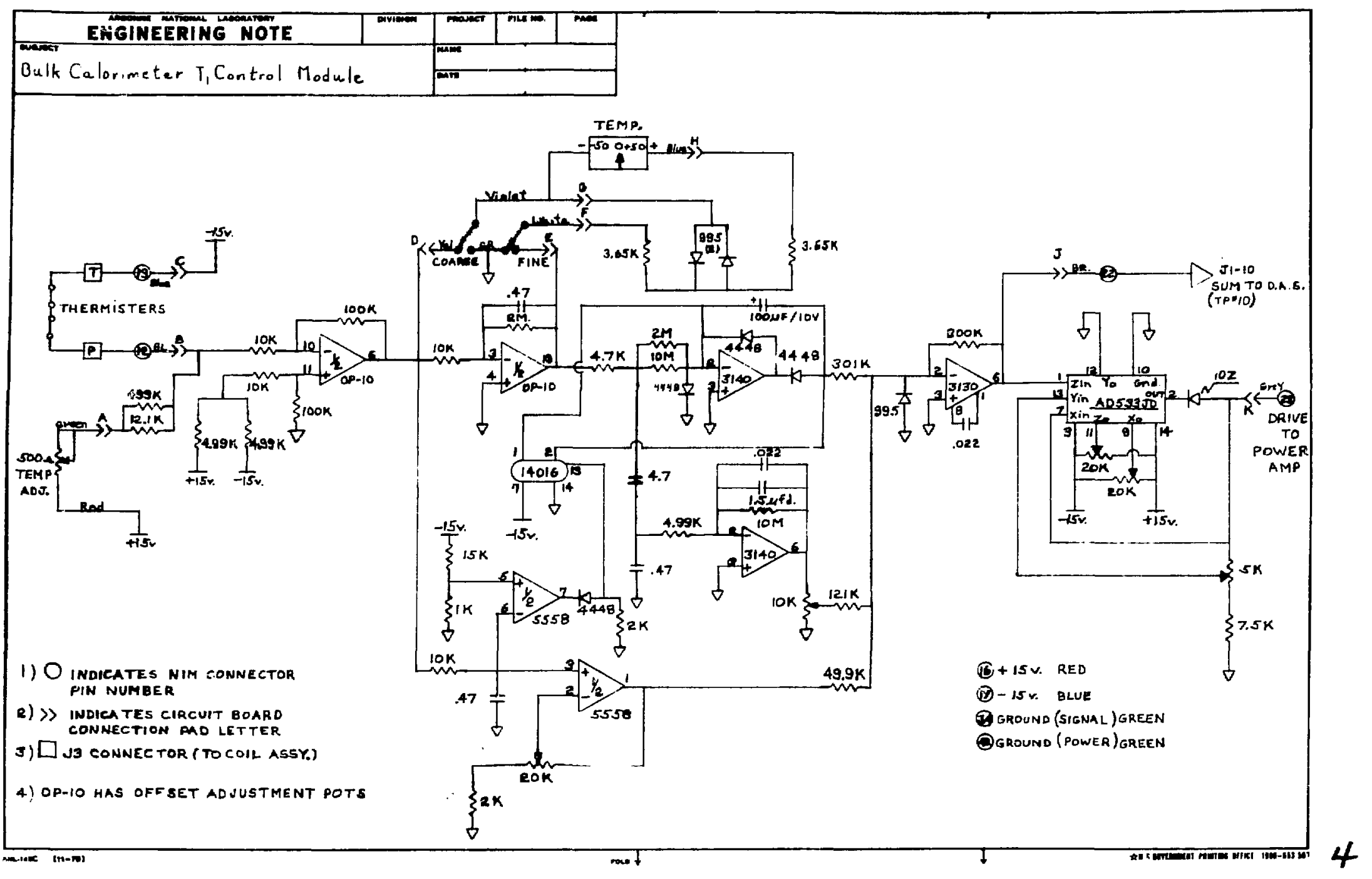




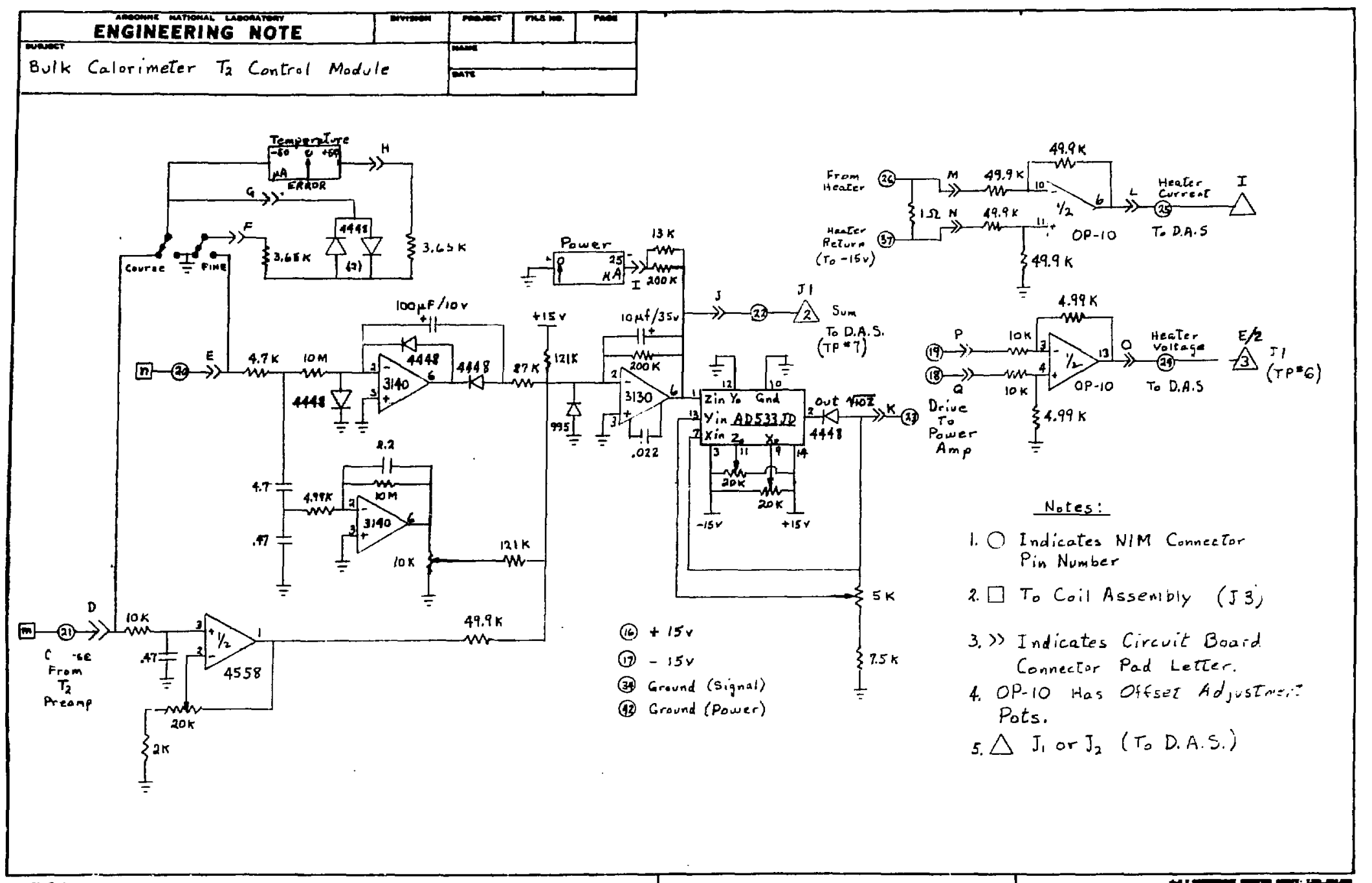




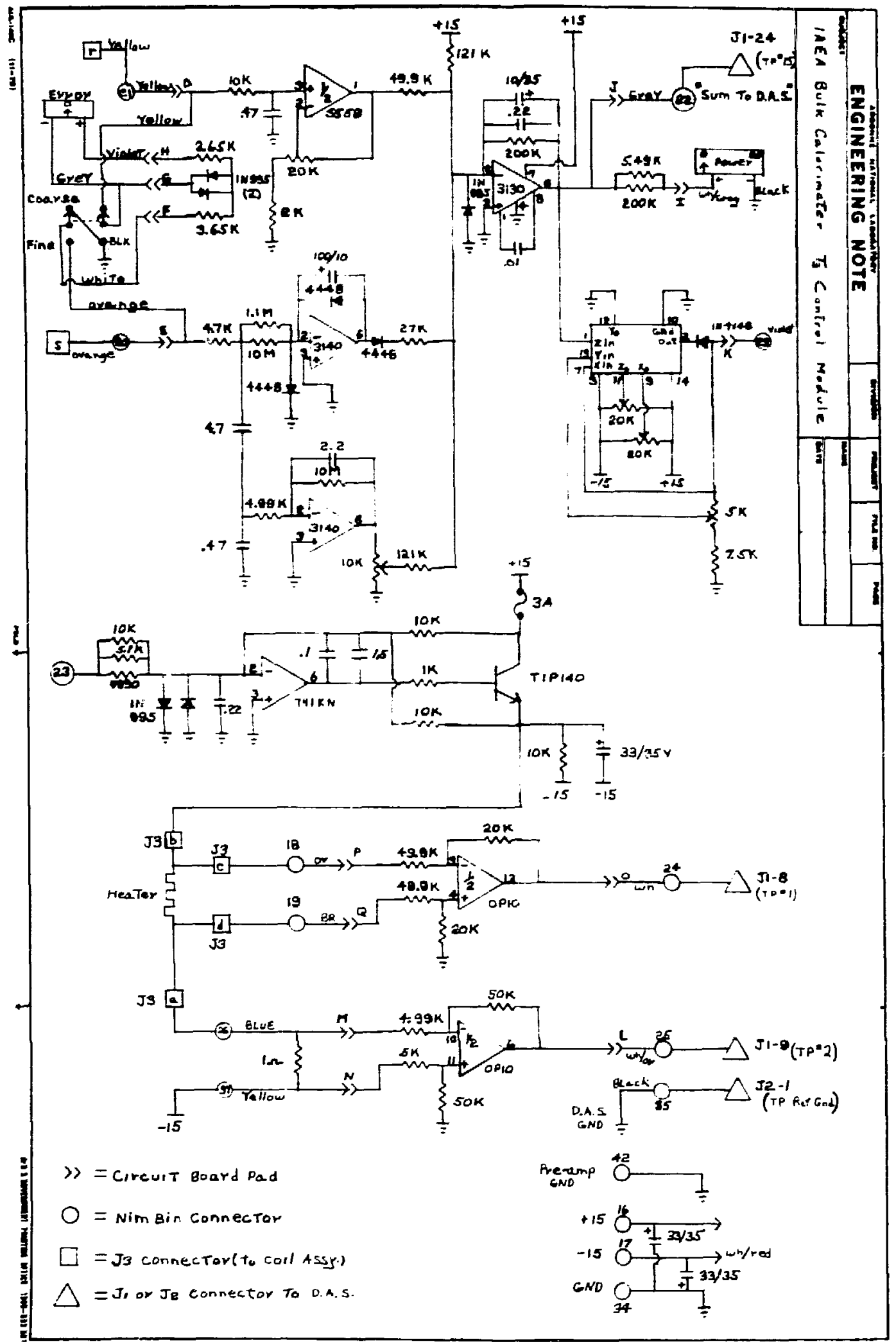




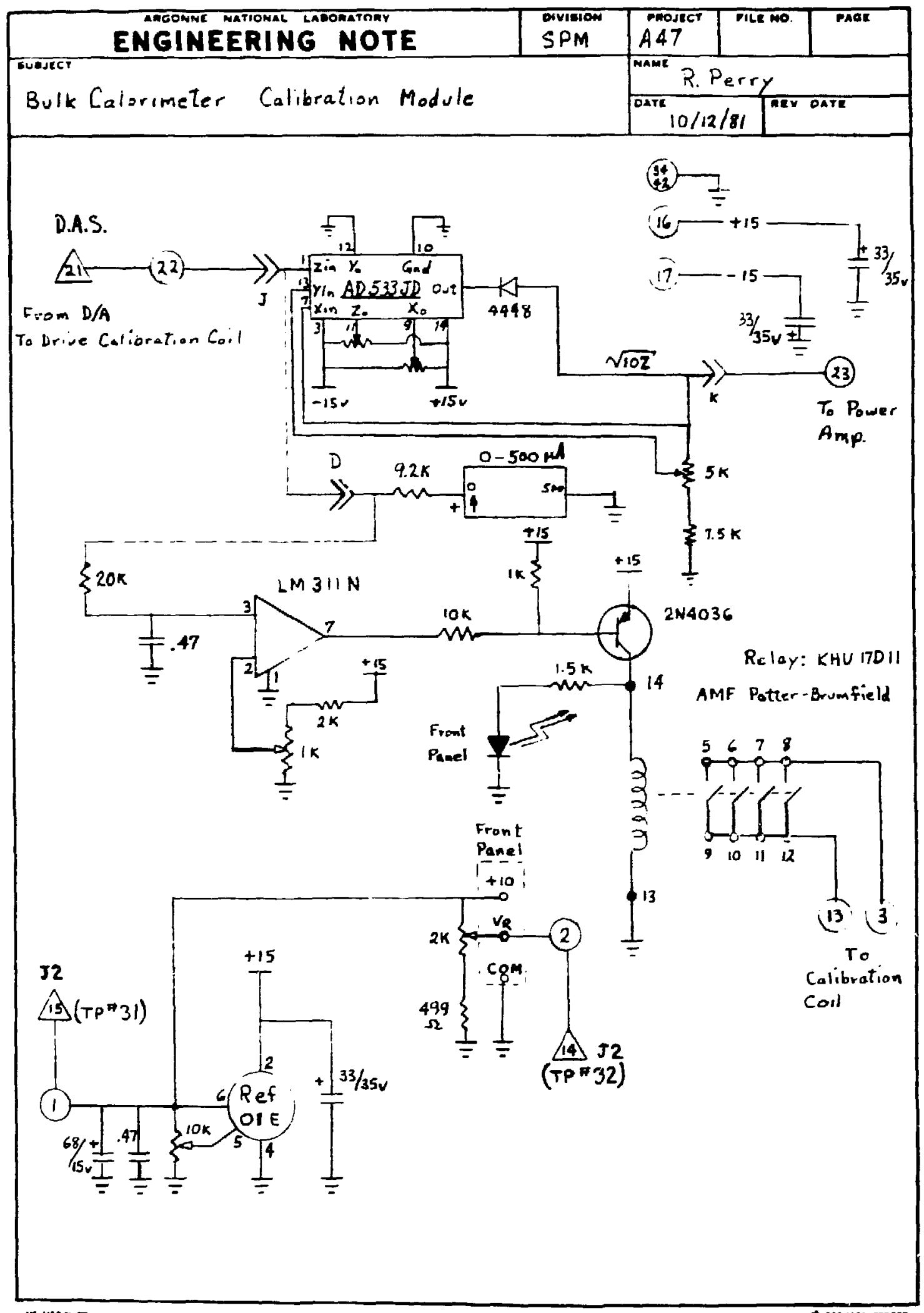




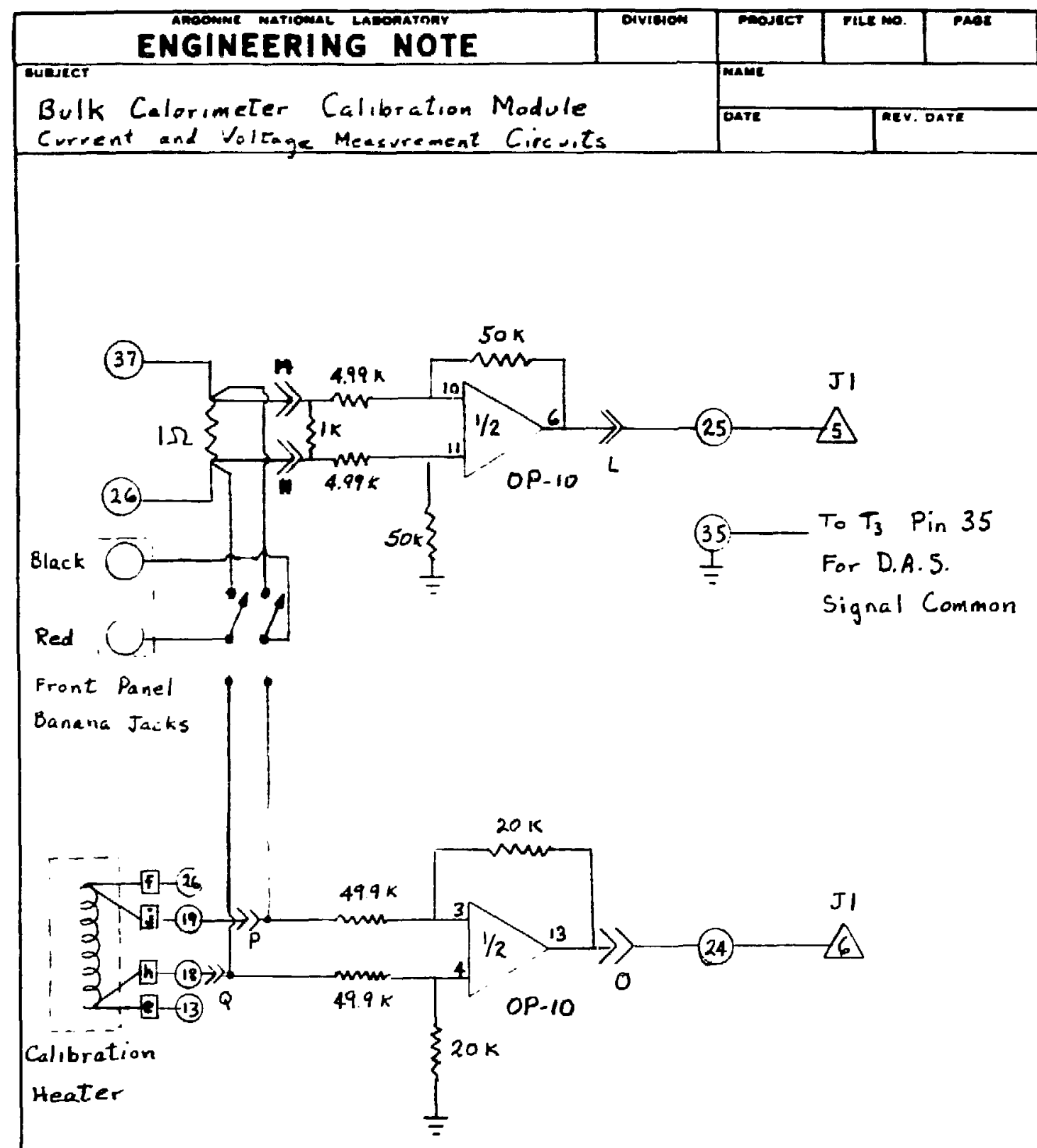




\begin{tabular}{|c|c|c|c|c|}
\hline PIn & Color & From & Description & est Point \\
\hline 1 & $\mathrm{~N} / \mathrm{C}$ & -- & & (8) \\
\hline 2 & Brown & $T 2-22$ & Sum $(T 2)$ & 7 \\
\hline 3 & Gray & $T 2-24$ & T2 E (Heater voltage) & 6 \\
\hline 4 & $\mathrm{~N} / \mathrm{C}$ & -- & & (5) \\
\hline 5 & White & $\mathrm{Cal}-25$ & Cal I (Heater current) & 4 \\
\hline 6 & Gray & $\mathrm{Cal}-24$ & Cal E (Heater voltage) & 3 \\
\hline 7 & White & $\mathrm{T} 3-25$ & T3 I (Heater current) & 2 \\
\hline 8 & Gray & $T 3-24$ & T3 E (Heater voltage) & 1 \\
\hline 9 & $\mathrm{~N} / \mathrm{C}$ & - & & (9) \\
\hline 10 & Brown & $\mathrm{T} 1-22$ & Sum $(T 1)$ & 10 \\
\hline 11 & $\mathrm{~N} / \mathrm{C}$ & -- & & (11) \\
\hline 12 & Green (18) & Aux -24 & Aux $+15 \vee$ for DAS (Com) & - \\
\hline 13 & Black & & Power supply ground & - \\
\hline 14 & Ren & $+15 \mathrm{v}$ & Power supply for DAS & - \\
\hline 15 & Blue & $-15 \mathrm{~V}$ & Power supply for DAS & - \\
\hline 16 & Green & $5 \vee$ Mod -10 & $+5 v$ to DAS & - \\
\hline 17 & Violet & $5 V$ Mod -14 & $+5 \mathrm{~V}$ sense wire & - \\
\hline 18 & Gray & $5 \vee$ Mod -13 & $5 \mathrm{~V}$ Com. sense wi re & -- \\
\hline 19 & White & 5 V Mod -3 & $5 \mathrm{~V}$ Com. to DAS & -- \\
\hline 20 & $\operatorname{Red}(18)$ & Aux -22 & Aux $+15 \vee$ for DAS (Pos.) & -- \\
\hline 21 & $\mathrm{~N} / \mathrm{C}$ & -- & & (12) \\
\hline 22 & Red & $+15 / 2$ & Pos. from T3\& T2 preamp & 13 \\
\hline 23 & Blue & $-15 / 2$ & Neg. located in coill assy & 14 \\
\hline 24 & Brown & $T^{3}-22$ & Sum & 15 \\
\hline 25 & $N / C$ & -- & & (16) \\
\hline
\end{tabular}




\section{J2 CONNECTOR - BULK CALORIMFTER}

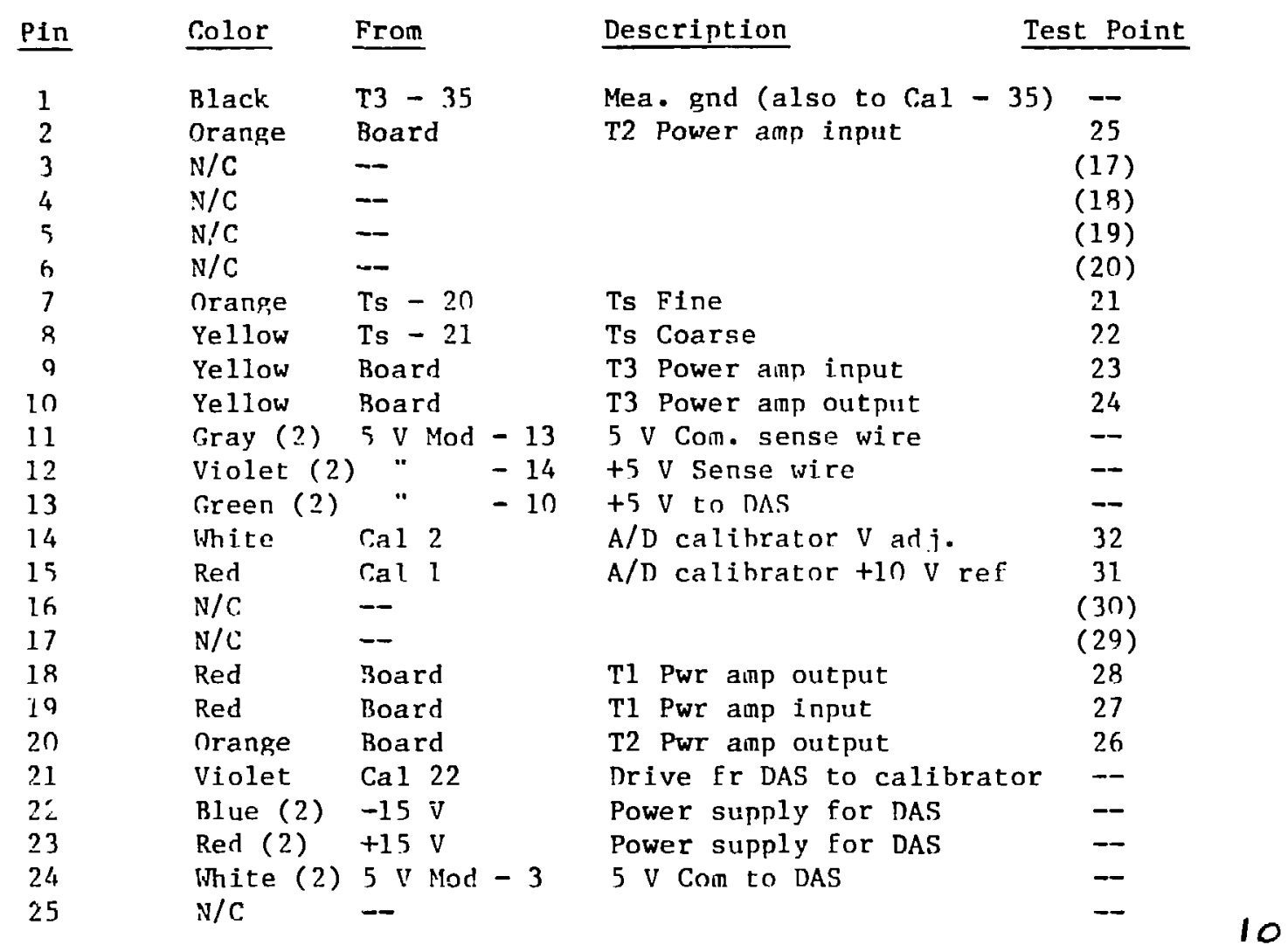




\section{J3 CONNECTOR - BULK CALORIMETER}

\begin{tabular}{|c|c|c|c|}
\hline$\underline{P i n}$ & Color & To & Description \\
\hline A & Orange & Ts -12 & \\
\hline $\begin{array}{l}\mathrm{B} \\
\mathrm{C}\end{array}$ & Blue (18) & -- & Ts Sense thermistors \\
\hline D & Yellow & $\mathrm{Ts}-13$ & \\
\hline $\begin{array}{l}E \\
F\end{array}$ & $\begin{array}{l}\text { N/C } \\
\text { Black (18) }\end{array}$ & $-\overline{-15} \mathrm{~V}$ & To TB heater \\
\hline $\mathrm{H}$ & Orange & $T B-12$ & \\
\hline$J$ & $\mathrm{~N} / \mathrm{C}$ & - & TB Sense thermistors \\
\hline $\mathrm{K}$ & $\mathrm{N} / \mathrm{C}$ & - & \\
\hline L & Yellow & $T B-13$ & \\
\hline M & Red (18) & $\mathrm{T} 1$ & Power amp output \\
\hline $\mathrm{N}$ & Black (18) & $-1.5 \mathrm{~V}$ & 11 Healet \\
\hline $\mathbf{p}$ & Orange & $\mathrm{T} 1-12$ & \\
\hline $\mathrm{R}$ & $\mathrm{N} / \mathrm{C}$ & -- & T1 Sense thermiscors \\
\hline S & $\mathrm{N} / \mathrm{C}$ & - & I1 Sense tnermiscors \\
\hline $\mathrm{T}$ & Yellow & $\mathrm{T} 1-13$ & \\
\hline $\mathrm{U}$ & & $\mathrm{T} 2$ & Power amp output \\
\hline V & B1ack (18) & $\mathrm{T} 2-26$ & \\
\hline W & Blue & $\mathrm{T} 2-18$ & T2 Heater voltage sense \\
\hline $\mathrm{x}$ & Blue & $\mathrm{T} 2-19$ & \\
\hline $\begin{array}{l}\mathrm{Y} \\
\mathrm{Z}\end{array}$ & Violet & $\begin{array}{l}\text { Ts }-26 \\
\text { Ts }-11\end{array}$ & Drive to Ts crydon [relay (S.S.)] \\
\hline Z & White & Ts -11 & 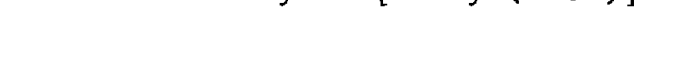 \\
\hline $\mathbf{a}$ & Yellow (18) & T3 - 26 & T3 Heater \\
\hline h & Ye11ow (18) & T3 & Power amp output \\
\hline $\begin{array}{c}4 \\
c\end{array}$ & $\begin{array}{l}\text { Green } \\
\text { Green }\end{array}$ & $\mathrm{T} 3-18$ & T3 Heater voltage sense \\
\hline & Green & $13-19$ & 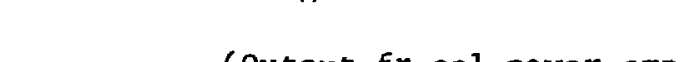 \\
\hline e & Green (18) & $\mathrm{Ca} 1-13$ & (Output fr cal power amp \\
\hline $\mathbf{f}$ & Green (18) & $\mathrm{Cal}-26$ & $\begin{aligned} \text { Cal heater } & \text { goes to Cal-3 to connect } \\
& \text { to relay) }\end{aligned}$ \\
\hline h & White & $\mathrm{Ca} 1-18$ & Cal heater voltage sense \\
\hline j & White & $\mathrm{Cal}-19$ & \\
\hline k & $\mathrm{N} / \mathrm{C}$ & & \\
\hline 1 & $\mathrm{~N} / \mathrm{C}$ & & \\
\hline $\mathrm{m}$ & Yellow & $\mathrm{T} 2-21$ & \\
\hline $\mathrm{n}$ & Orange & $\mathrm{T} 2-20$ & \\
\hline$p$ & Black (18) & Loose & \\
\hline $\mathbf{r}$ & Ye11ow & T3 - 21 & \\
\hline s & Orange & $\mathrm{T} 3-20$ & \\
\hline
\end{tabular}




\begin{tabular}{|c|c|c|c|}
\hline Pin & Color & To & Description \\
\hline$t$ & Black (18) & $T 3-42$ & Preamp ground reference \\
\hline $\mathbf{u}$ & Red & +15 & from preamp \\
\hline $\mathrm{v}$ & Blue & -15 & from preamp \\
\hline $\mathbf{w}$ & Red & Ts - YSI & \\
\hline $\mathrm{x}$ & Black & & \\
\hline y & Green (18) & YSI Common & \\
\hline$z$ & Violet & $T B-Y S I$ & \\
\hline AA & Black & $1 B=Y \Delta L$ & \\
\hline$B B$ & White & TI - YSI & \\
\hline C. & Black & +1 & \\
\hline DD & Orange & $\mathrm{I} 2-\mathrm{YSI}$ & \\
\hline $\mathrm{EE}$ & Black & $12-Y S 1$ & \\
\hline $\mathrm{FF}$ & ien & T3 - YSI & \\
\hline HII & Black & $10-101$ & \\
\hline $\mathrm{J} \cdot \mathrm{J}$ & Black (18) & Lonse & \\
\hline KK & $\mathrm{N} / \mathrm{C}$ & & \\
\hline LL & $\mathrm{N} / \mathrm{C}$ & & \\
\hline MM & $\mathrm{N} / \mathrm{C}$ & & \\
\hline NN & $\mathrm{N} / \mathrm{C}$ & & \\
\hline
\end{tabular}


71

APPENDIX B

Schematics for Data Acquisition System

Sheets 1 through 7 


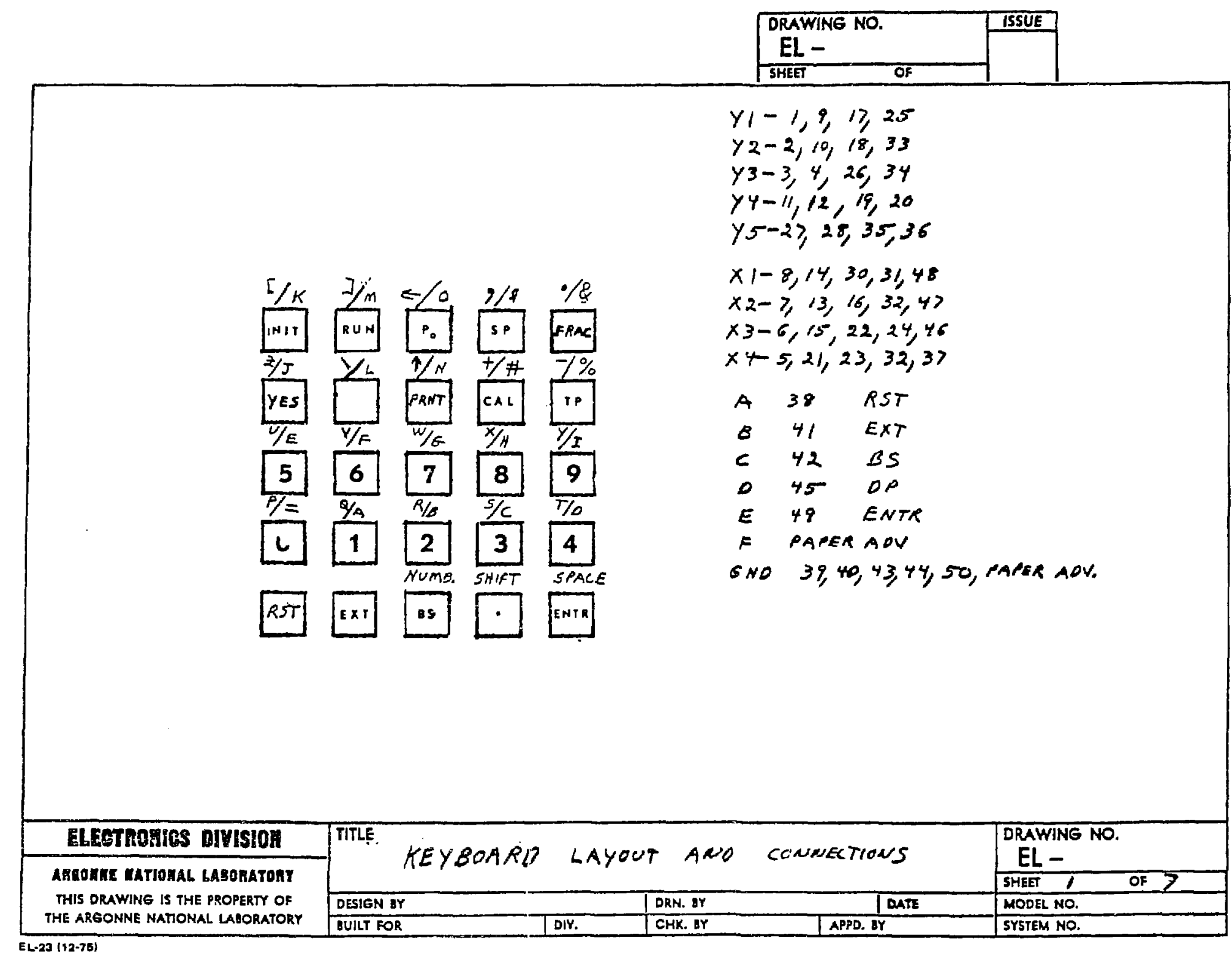




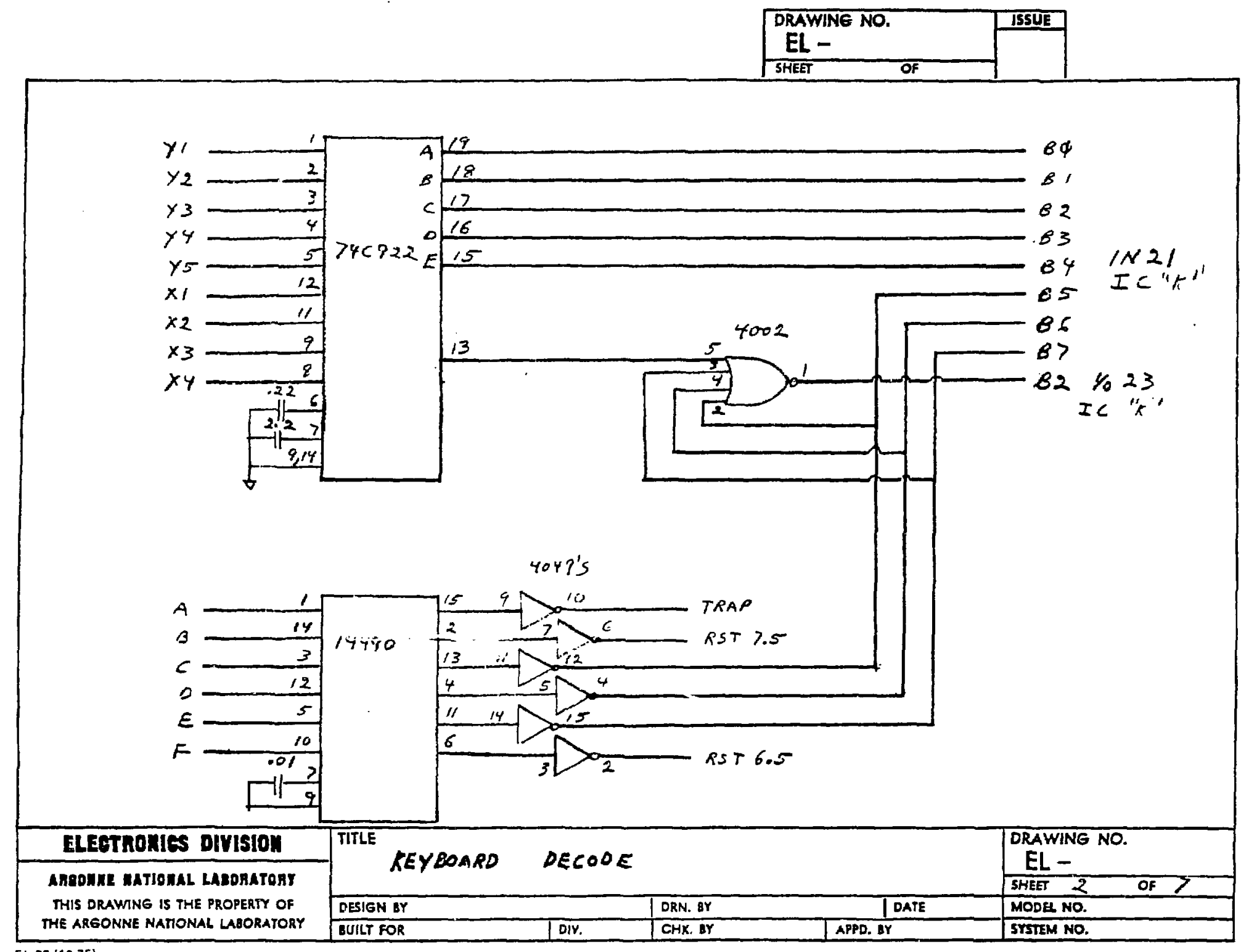




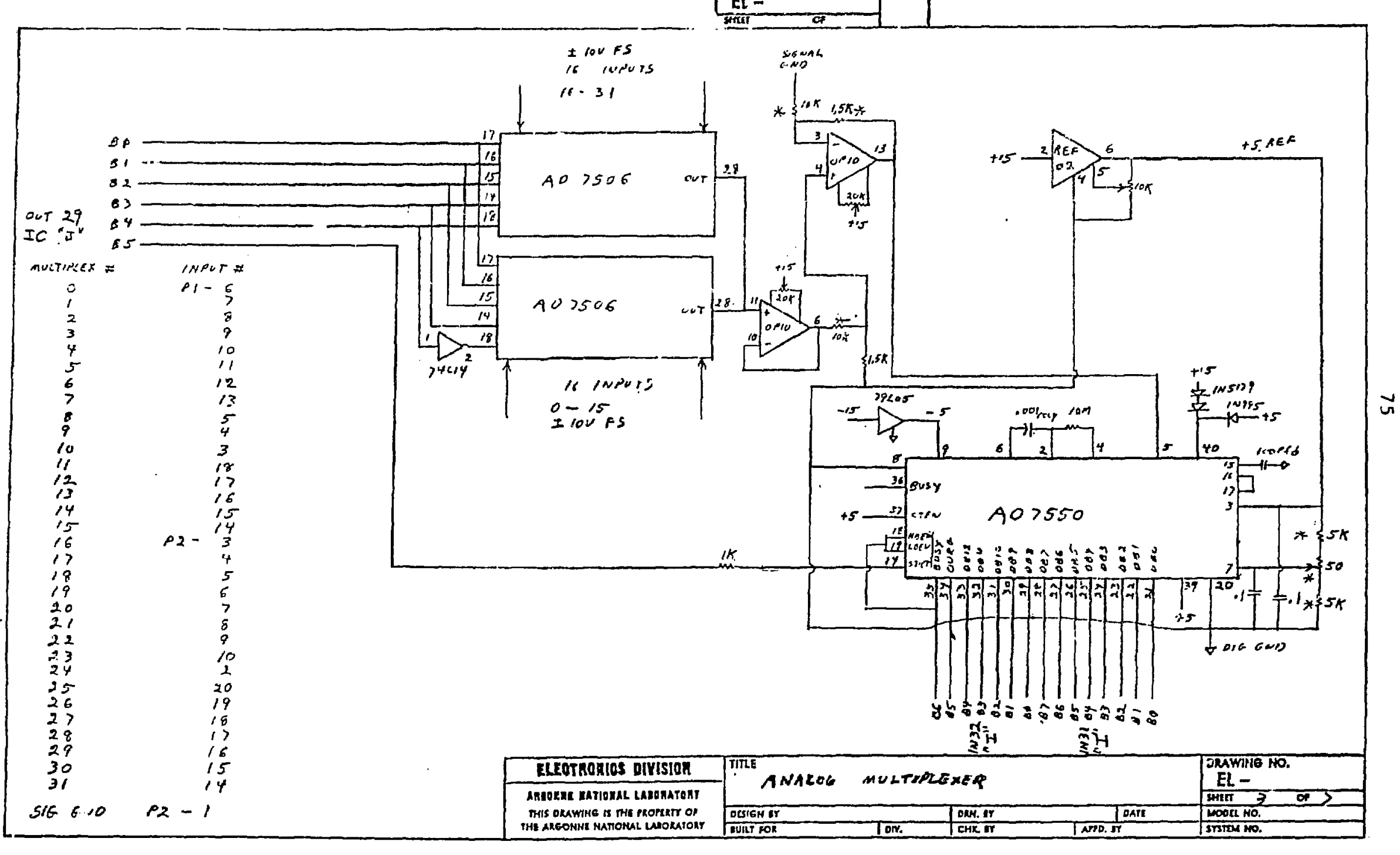




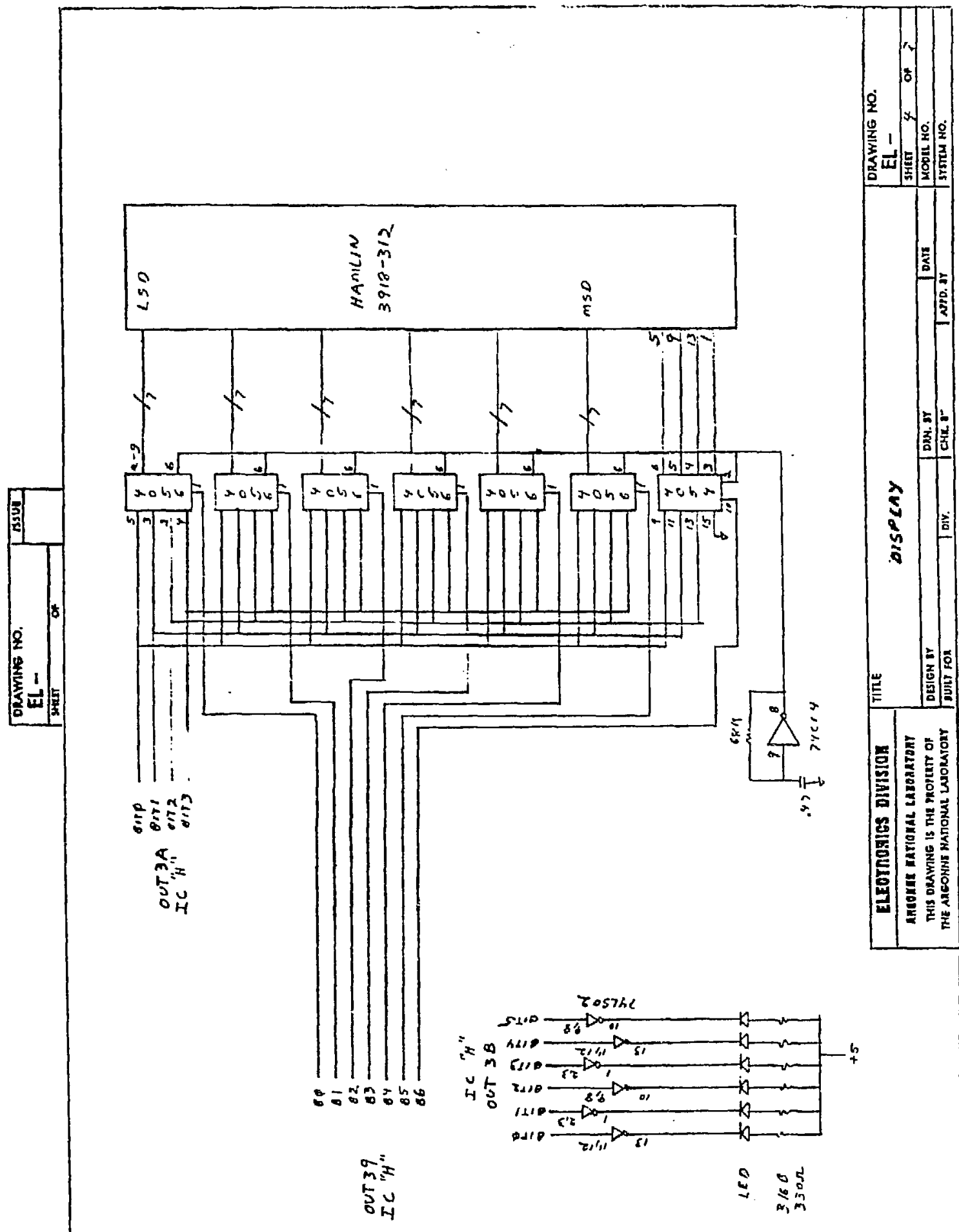




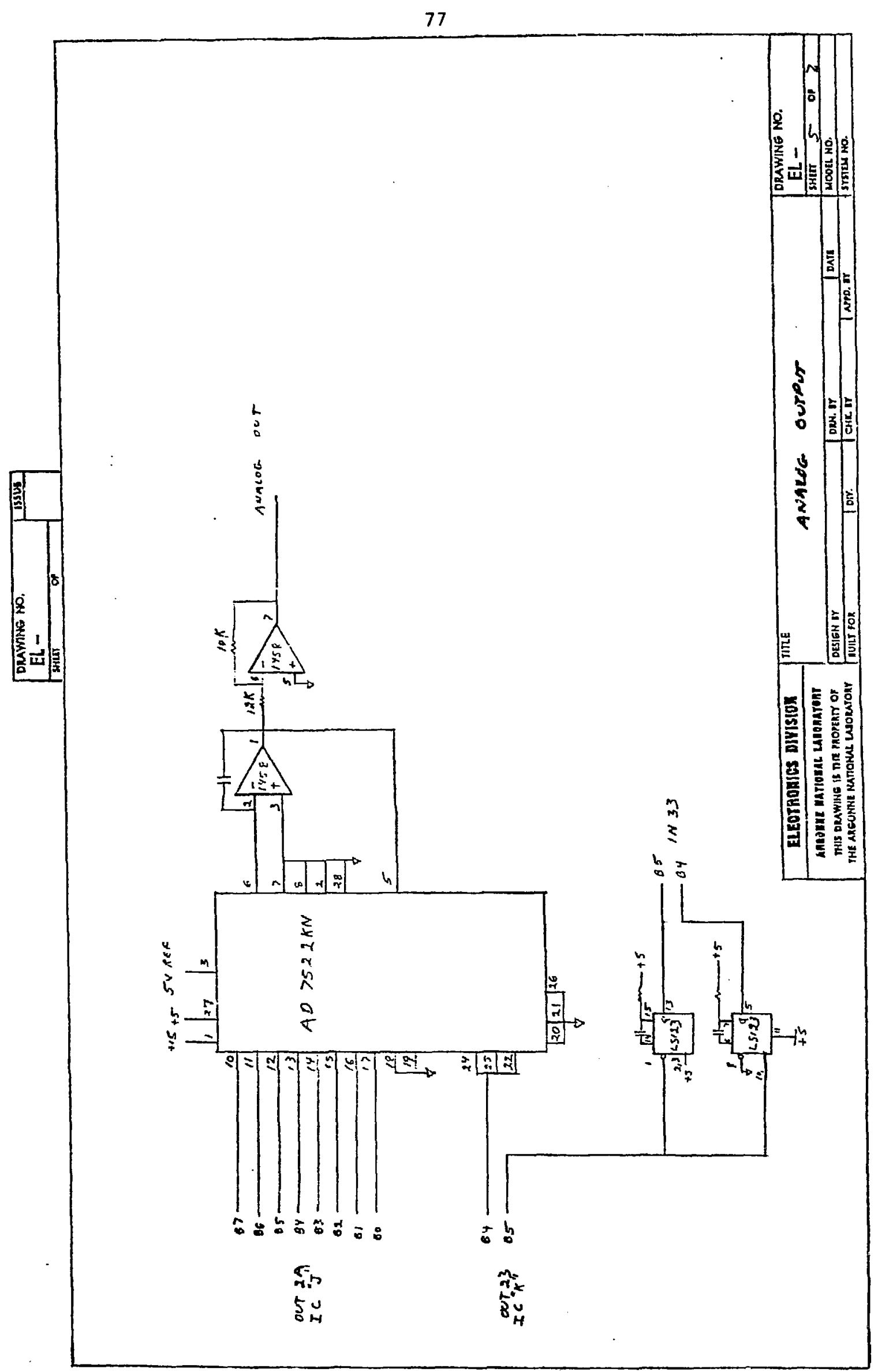




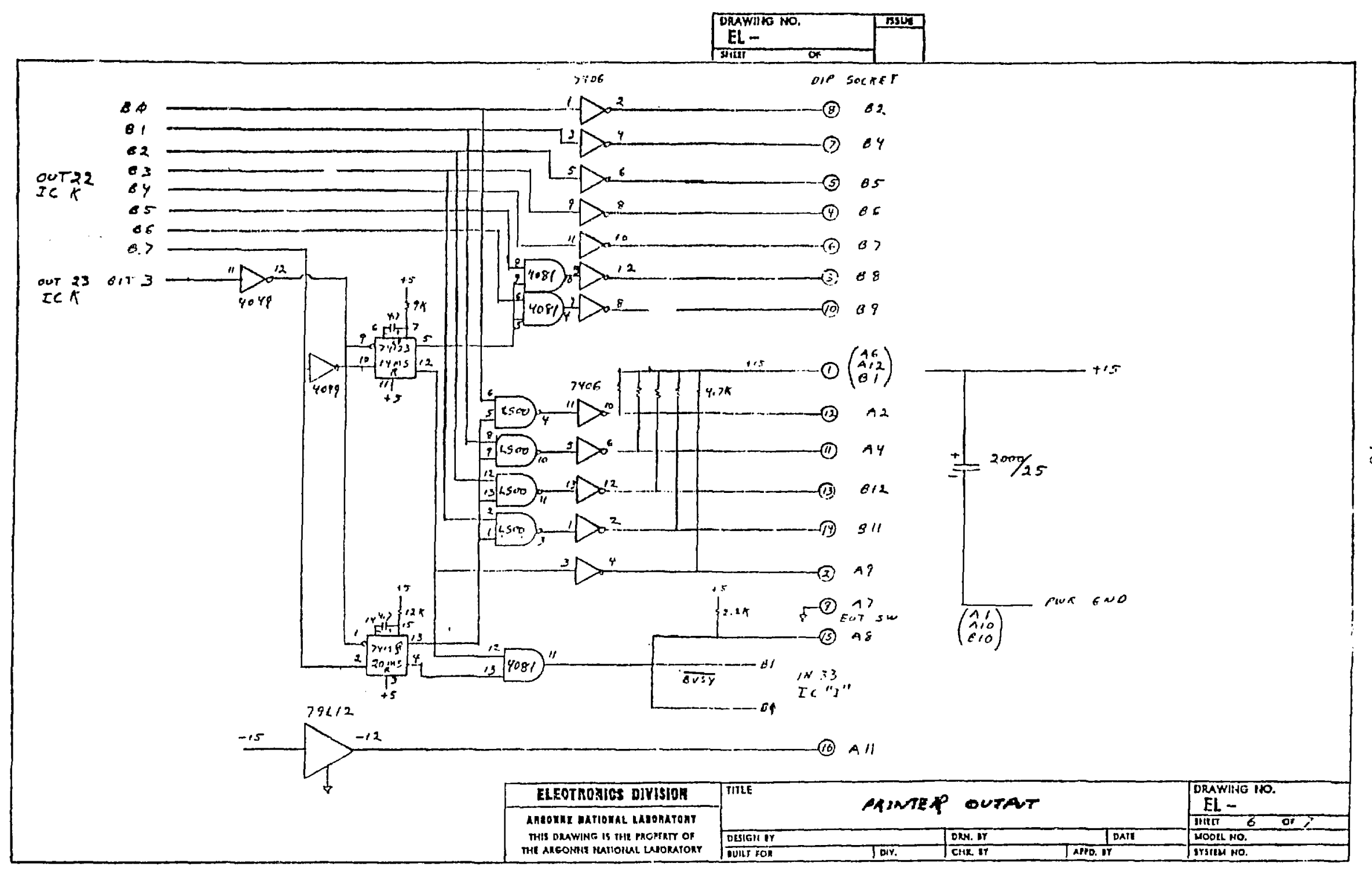




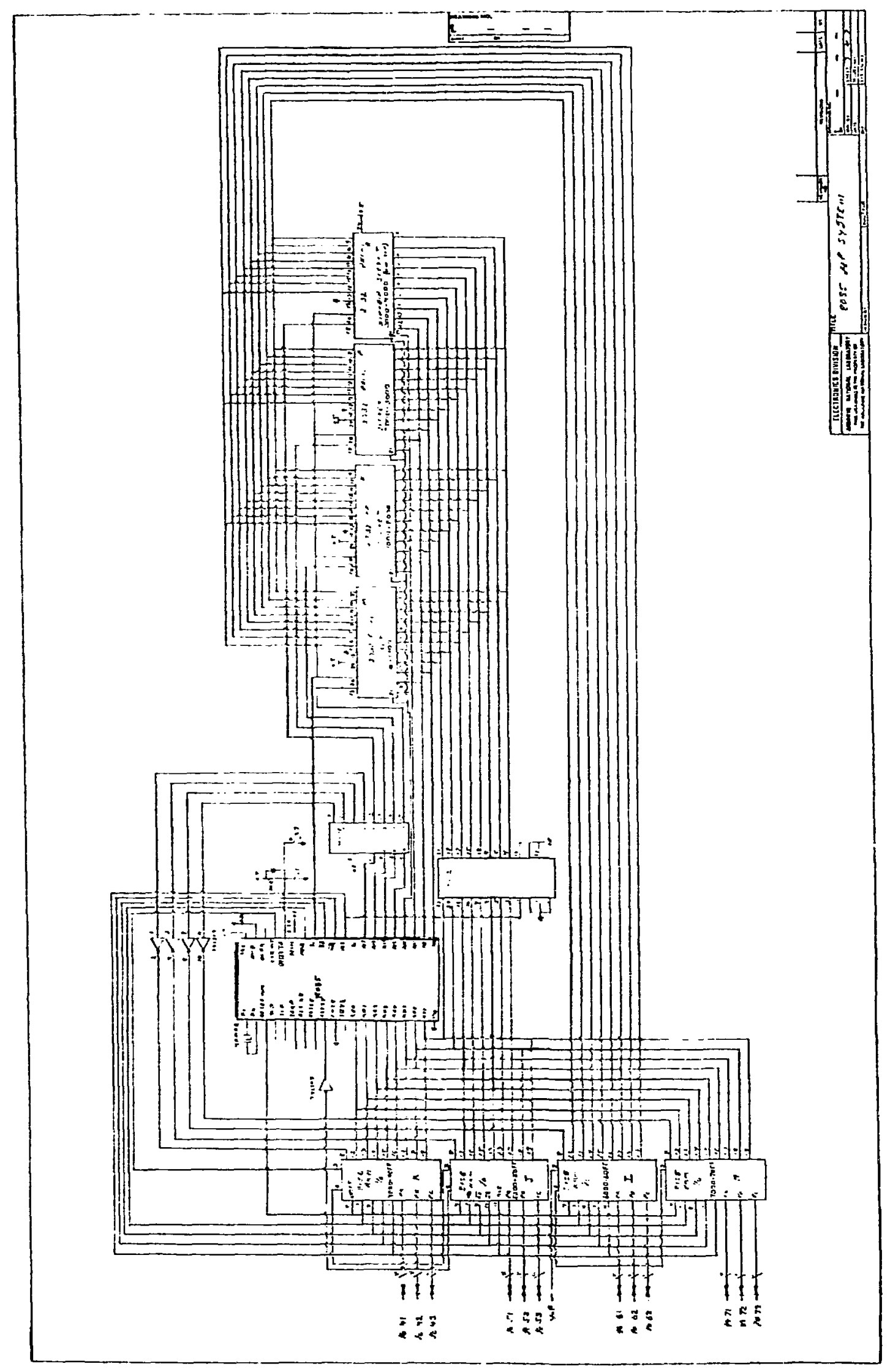

